DOE/ID-22249

Prepared in cooperation with the U.S. Department of Energy

\title{
Transmissivity and Geophysical Data for Selected Wells at and Near the Idaho National Laboratory, Idaho, 2017-18
}

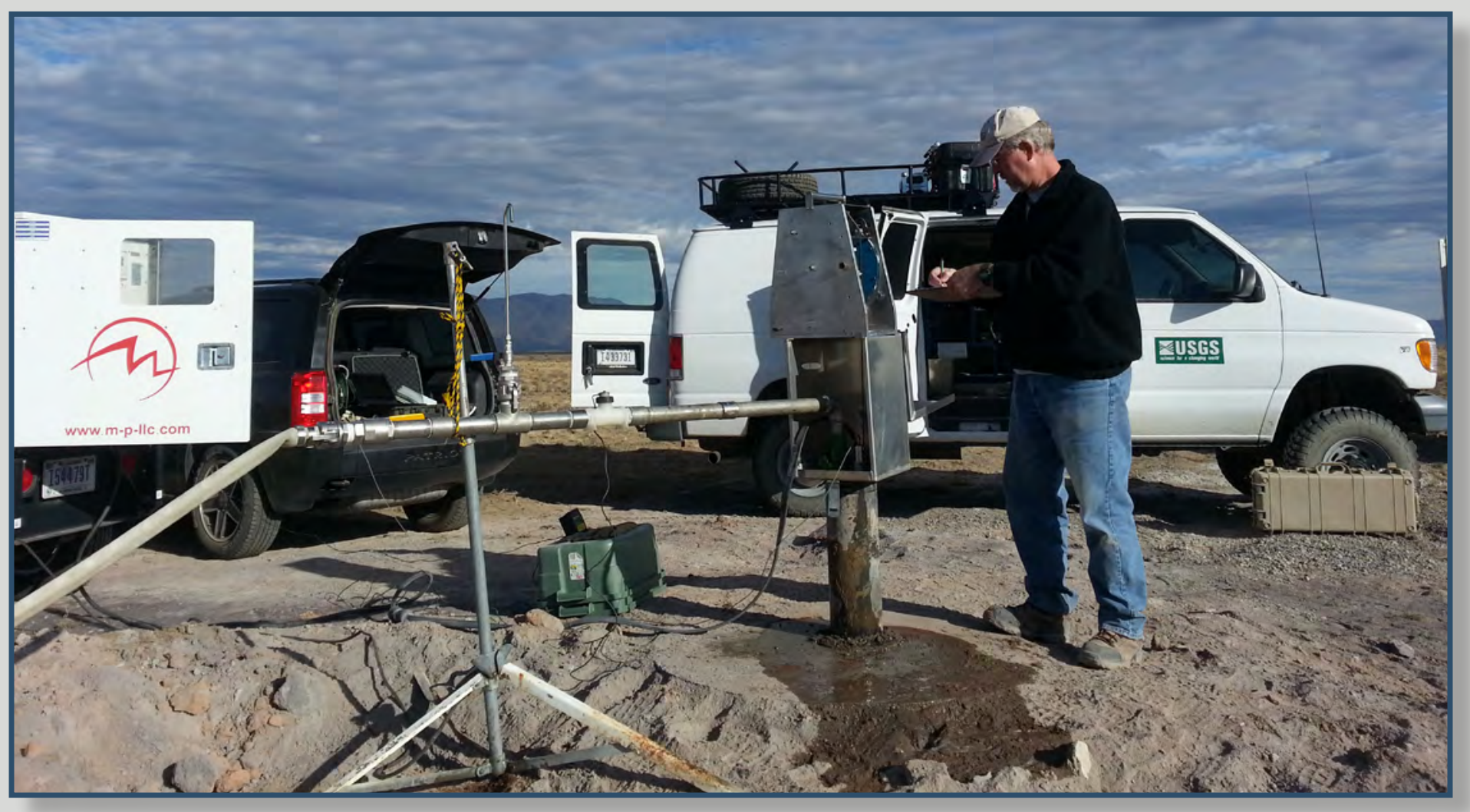

Scientific Investigations Report 2019-5134 
Cover: U.S. Geological Survey (USGS) staff monitoring USGS well TAN 2272, at the Idaho National Laboratory, Idaho. Photograph by Brian Twining, USGS, September 24, 2013. 


\section{Transmissivity and Geophysical Data for Selected Wells at and Near the Idaho National Laboratory, Idaho, 2017-18}

By Brian V. Twining and Neil V. Maimer

DOE/ID-22249

Prepared in cooperation with the U.S. Department of Energy

Scientific Investigations Report 2019-5134 


\title{
U.S. Department of the Interior DAVID BERNHARDT, Secretary
}

\author{
U.S. Geological Survey \\ James F. Reilly II, Director
}

U.S. Geological Survey, Reston, Virginia: 2019

For more information on the USGS - the Federal source for science about the Earth, its natural and living resources, natural hazards, and the environment-visit https://www.usgs.gov or call 1-888-ASK-USGS.

For an overview of USGS information products, including maps, imagery, and publications, visit https://store.usgs.gov.

Any use of trade, firm, or product names is for descriptive purposes only and does not imply endorsement by the U.S. Government.

Although this information product, for the most part, is in the public domain, it also may contain copyrighted materials as noted in the text. Permission to reproduce copyrighted items must be secured from the copyright owner.

Suggested citation:

Twining, B.V., and Maimer, N.V., 2019, Transmissivity and geophysical data for selected wells located at and near the Idaho National Laboratory, Idaho, 2017-18: U.S. Geological Survey Scientific Investigations Report 2019-5134, 30 p. plus appendixes, http://dx.doi.org/10.3133/sir20195134.

ISSN 2328-0328 (online) 


\section{Contents}

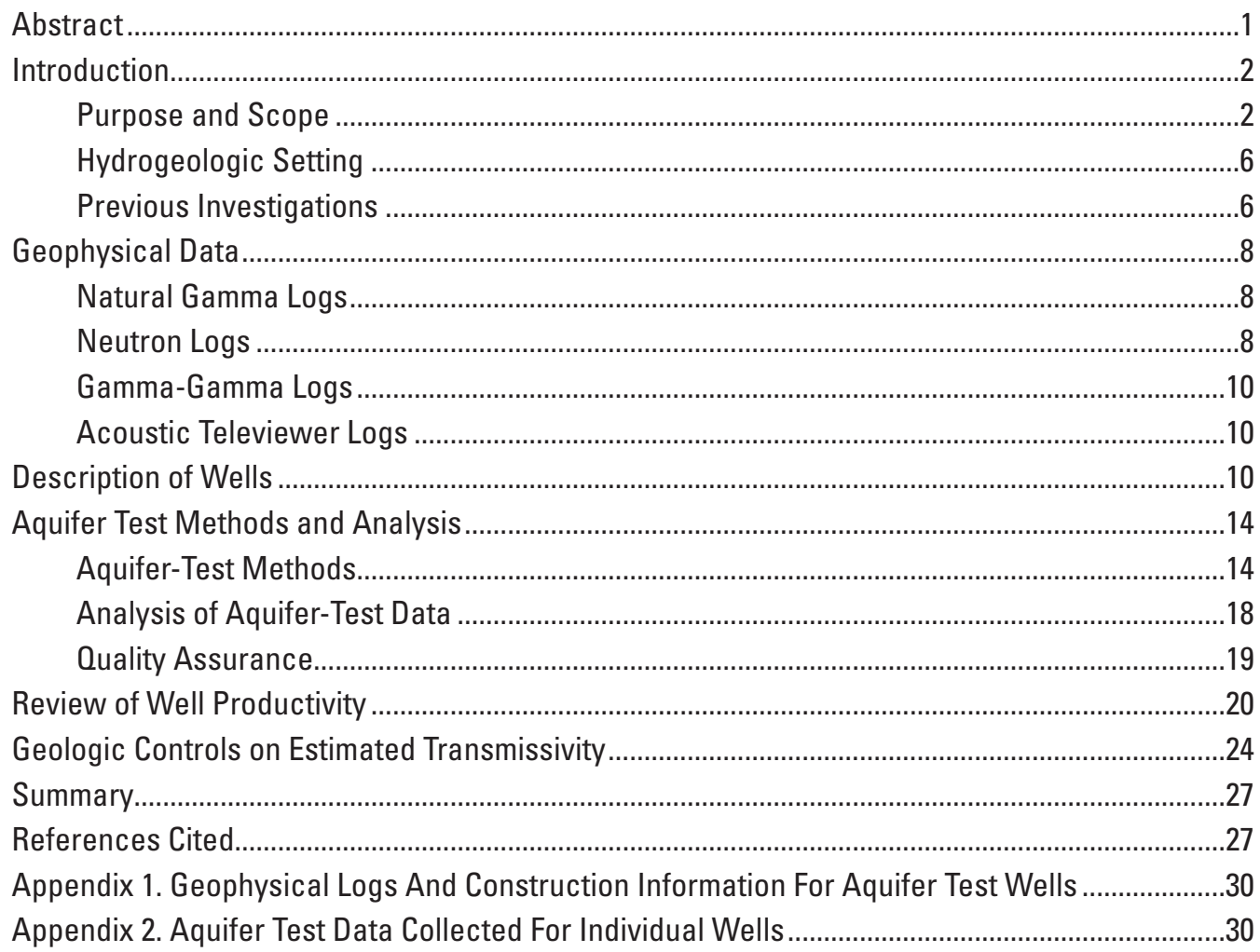




\section{Figures}

1. Map showing location of selected facilities at the Idaho National Laboratory, Idaho.....3

2. Map showing location of monitor wells selected as part of this study and selected facilities at and near the Idaho National Laboratory, Idaho

3. Map showing location of wells and selected facilities at the Advanced Test Reactor Complex and Idaho Nuclear Technology and Engineering Center, Radioactive Waste Management Complex, and Naval Reactors Facility, Idaho National Laboratory, Idaho.

4. Map showing altitude of the water table in the eastern Snake River Plain aquifer at and near the Idaho National Laboratory, Idaho, March-May 2017

5. Geophysical logs of data for well USGS 146, similar to wells in appendix 1 files, and showing natural gamma, well completion, neutron, gamma-gamma density, acoustic televiewer, and comments at the Idaho National Laboratory, Idaho

6. Diagram showing configuration of wells, submersible pump, and calibrated e-tape for wells included in this study at and near the Idaho National Laboratory, Idaho

7. Graphs showing water levels in wells USGS 26, Site 14, USGS 12, and USGS 9, indicating water-level change through the center of the Idaho National Laboratory, 1988-2018

8. Map showing transmissivity ranges of individual wells and inferred areas of low transmissivity for wells and vent corridors located at and near the Idaho National Laboratory, Idaho.

\section{Tables}

1. List of monitor well sites included as part of this study at and near the Idaho National Laboratory, Idaho.

2. Data on specific capacity and transmissivity for monitor well sites at and near the Idaho National Laboratory, Idaho, 2017-18

3. Comparison of aquifer test data collected for 65 wells using current data and data previously presented at individual well sites at and near the Idaho National Laboratory, Idaho

4. Transmissivity categories for monitor well sites at and near the Idaho National Laboratory, Idaho

5. Relation of individual wells with low and very low transmissivity to vent

corridors at and near the Idaho National Laboratory, Idaho. 


\section{Conversion Factors}

U.S. customary units to International System of Units

\begin{tabular}{|c|c|c|}
\hline Multiply & By & To obtain \\
\hline \multicolumn{3}{|c|}{ Length } \\
\hline inch (in.) & 2.54 & centimeter $(\mathrm{cm})$ \\
\hline foot $(\mathrm{ft})$ & 0.3048 & meter (m) \\
\hline mile (mi) & 1.609 & kilometer $(\mathrm{km})$ \\
\hline \multicolumn{3}{|c|}{ Area } \\
\hline square mile $\left(\mathrm{mi}^{2}\right)$ & 2.590 & square kilometer $\left(\mathrm{km}^{2}\right)$ \\
\hline \multicolumn{3}{|c|}{ Specific capacity } \\
\hline $\begin{array}{l}\text { gallon per minute per foot } \\
([\mathrm{gal} / \mathrm{min}] / \mathrm{ft})\end{array}$ & 0.2070 & liter per second per meter $([\mathrm{L} / \mathrm{s}] / \mathrm{m})$ \\
\hline \multicolumn{3}{|c|}{ Hydraulic conductivity } \\
\hline foot per day $(\mathrm{ft} / \mathrm{d})$ & 0.3048 & meter per day $(\mathrm{m} / \mathrm{d})$ \\
\hline \multicolumn{3}{|c|}{ Hydraulic gradient } \\
\hline foot per mile ( $\mathrm{ft} / \mathrm{mi})$ & 0.1894 & meter per kilometer $(\mathrm{m} / \mathrm{km})$ \\
\hline \multicolumn{3}{|c|}{ Transmissivity* } \\
\hline foot squared per day $\left(\mathrm{ft}^{2} / \mathrm{d}\right)$ & 0.09290 & meter squared per day $\left(\mathrm{m}^{2} / \mathrm{d}\right)$ \\
\hline
\end{tabular}

\section{Datums}

Vertical coordinate information is referenced to the National Geodetic Vertical Datum of 1929 (NGVD 29).

Horizontal coordinate information is referenced to the North American Datum of 1927 (NAD 27).

Altitude, as used in this report, refers to distance above the vertical datum.

\section{Supplemental Information}

*Transmissivity: The standard unit for transmissivity is cubic foot per day per square foot times foot of aquifer thickness [(ft $\left.3 / \mathrm{d}) / \mathrm{ft}^{2}\right] \mathrm{ft}$. In this report, the mathematically reduced form, foot squared per day $\left(\mathrm{ft}^{2} / \mathrm{d}\right)$, is used for convenience. 


\section{Abbreviations}

$\begin{array}{ll}\text { ATR Complex } & \begin{array}{l}\text { Advanced Test Reactor Complex (formerly RTC, Reactor Technology Complex } \\ \text { and TRA, Test Reactor Area) }\end{array} \\ \text { ATV } & \begin{array}{l}\text { acoustic televiewer } \\ \text { below land surface }\end{array} \\ \text { BLS } & \text { Central Facilities Area } \\ \text { CFA } & \text { U.S. Department of Energy } \\ \text { DOE } & \text { Environmental Protection Agency } \\ \text { EPA } & \text { eastern Snake River Plain } \\ \text { ESRP } & \text { Idaho National Laboratory } \\ \text { INL } & \text { Idaho Nuclear Technology and Engineering Center } \\ \text { INTEC } & \text { Materials and Fuels Complex } \\ \text { MFC } & \text { Radioactive Waste Management Complex } \\ \text { RWMC } & \text { Test Area North } \\ \text { TAN } & \text { Test Reactor Area } \\ \text { TRA } & \text { U.S. Geological Survey } \\ \text { USGS } & \end{array}$




\title{
Transmissivity and Geophysical Data for Selected Wells at and Near the Idaho National Laboratory, Idaho, 2017-18
}

\author{
By Brian V. Twining and Neil V. Maimer
}

\section{Abstract}

The U.S. Geological Survey, in cooperation with the U.S. Department of Energy, conducted aquifer tests during 2017-18 on 101 wells at and near the Idaho National Laboratory (INL), Idaho, to define the hydraulic characteristics for individual wells. These were short-duration aquifer tests, conducted with a limited number of observations during routine sampling. Pumped intervals (water columns) for individual wells ranged from 12 to 790 feet (ft). Semi-constant discharge rates during aquifer testing ranged from 1 to 45 gallons per minute (gal/ $\mathrm{min}$ ), water-level response to pumping ranged from no observed drawdown to $52.4 \mathrm{ft}$, and length of aquifer tests for individual wells ranged from 10 to 160 minutes. Individual well data were analyzed to estimate the capacity of the well to produce water (specific capacity) and to estimate values for transmissivity. Estimates of specific capacity for individual wells ranged from less than $(<) 1.0$ to greater than $(>) 3.0 \times$ $10^{3}$ gallons per minute per foot; estimates of transmissivity for individual wells ranged from 2.0 to $>5.4 \times 10^{5}$ feet squared per day $\left(\mathrm{ft}^{2} / \mathrm{d}\right)$.

Geophysical log data, well construction information, and general geology for individual wells were presented and included in this report. Basic hydrogeologic features for individual wells were described, along with a composite of natural gamma, neutron, gamma-gamma dual density, and acoustic televiewer data (when available). The geophysical and geologic data were used to suggest the location and thickness of sediment layers along with fractured and dense basalt areas for individual wells. Geophysical data were used to describe the general geology where geologic descriptions and (or) driller notes were not available.

A simplified approach was used to complete aquifer testing for 101 individual wells during routine sampling. This approach involved using a dedicated submersible pump and a dedicated water-level measurement line to stress the well through pumping while simultaneously taking water-level measurements. Discharge rates were considered semi-constant and water levels were measured using an electric tape. These tests were done during routine sampling; therefore, the aquifer test data were limited to the time it took to purge the well before sampling activities. All 101 single-well aquifer tests were analyzed using the specific-capacity method to approximate transmissivity.

\begin{abstract}
Review of well productivity included examination of aquifer test data for 65 wells collected during this investigation and previous investigations spanning about 30 years. Additionally, hydrograph data were presented for a similar period of record at four select well locations to provide a snapshot of the general water-level change along the north end of the INL, the center of the INL, and along the south end of the INL. Eleven of the 65 wells had a change in well productivity - six wells with increased productivity and five wells with decreased productivity. Hydrograph data suggest that water-level responses over a 30-year period can vary by almost $25 \mathrm{ft}$ between the northern to southern end of the INL, with the largest water-level declines of about $35 \mathrm{ft}$ at the northern end of the INL. Near the southern part of the INL, water-level declines were about $10 \mathrm{ft}$ for that same 30-year period of record. Declines in water levels and changes in well conditions seemed to affect about 17 percent of individual wells; however, 83 percent of wells did not have any changes in well conditions. Observations of well conditions were based on the wells used for this study and do not represent wells that are no longer in service.

Estimates of transmissivity were divided into five categories, ranging from very low to very high. About 53 percent of the wells tested suggest high or very high transmissivity $\left(>10,000 \mathrm{ft}^{2} / \mathrm{d}\right)$, about 23 percent of the wells tested show low or very low (referred to as "lower") transmissivity $\left(\leq 1,000 \mathrm{ft}^{2} / \mathrm{d}\right)$, and about 24 percent of wells tested suggest moderate transmissivity $(>1,000$ to 10,000 $\mathrm{ft}^{2} / \mathrm{d}$ ). Transmissivity range(s) were developed for well data collected as part of this investigation.

Location of volcanic vent corridors along with dike systems under the subsurface were examined in conjunction with wells that indicate lower transmissivity $\left(\leq 1,000 \mathrm{ft}^{2} / \mathrm{d}\right)$ to develop inferred areas of lower transmissivity. The individual wells within the low and very low transmissivity category seem to correlate with select volcanic vent corridor areas identified in previous investigations. Based on data from 24 individual wells, eight inferred regions were identified that show low and very low transmissivity. The largest inferred area of lower transmissivity $\left(\leq 1,000 \mathrm{ft}^{2} / \mathrm{d}\right)$ seems to extend from the Lost River Range through the center of the INL and crosses the southern INL boundary near Atomic City. Seven other inferred regions of lower transmissivity $\left(>1,000 \mathrm{ft}^{2} / \mathrm{d}\right)$ are identified and occur along areas where volcanic vent corridors were previously identified.
\end{abstract}




\section{Introduction}

The Idaho National Laboratory (INL) was established by the U.S. Atomic Energy Commission, now the U.S. Department of Energy (DOE), in 1949 to build, operate, and test nuclear reactors. The scope of the work at the INL increased from the 1950s through the 1970s to include other nuclear-research programs, the reprocessing of spent nuclear fuel, and the storage and disposal of radioactive waste. A history of more than 60 years of waste disposal associated with the nuclear-reactor research and nuclear-fuel reprocessing at the INL has resulted in measurable concentrations of contaminants in the eastern Snake River Plain (ESRP) aquifer beneath the INL.

The INL covers an area of about $890 \mathrm{mi}^{2}$ and overlies the west-central part of the ESRP in southeastern Idaho (fig. 1). The underlying ESRP aquifer, designated as a sole source aquifer by the U.S. Environmental Protection Agency (2014), is a major source of water for agricultural, industrial, and domestic use. The U.S. Geological Survey (USGS), in cooperation with the DOE, has collected groundwater data at the INL since 1949. Much of the data that the USGS have collected has been used to provide baseline and current data concerning the migration and disposition of radioactive and chemical wastes in the eastern ESRP aquifer. The USGS conducted aquifer testing during routine groundwater sampling to capture well productivity over a broad scope of wells located throughout the INL. Because the USGS develops numerical models for the movement of groundwater and contaminants in the ESRP aquifer, updated hydrogeologic and borehole information is needed for ongoing studies at the INL (fig. 1). Updated hydraulic properties along with hydrogeologic information are important to help define groundwater movement as it relates to contaminant transport of waste plumes at the INL.

Monitor well sites identified as part of this study were selected from routine sample sites already scheduled to be sampled. About 116 monitor well sites were identified; however, tests were collected for 101 sites. Data could not be collected from 15 well sites owing to various well problems including submersible pump issues, measurement line obstructions, and (or) missing measurement line(s). Aquifer testing generally was completed during April, May, and October 2017; however, some measurements were redone during 2018 after repairs to individual wells were completed. Monitor wells considered for study were constructed and completed within the ESRP aquifer.

Monitor wells selected for this study all had dedicated submersible pumps along with dedicated water-level measurement lines. Most wells were run at full capacity, but the discharge rate was reduced at some wells if there were known productivity issues. Monitor wells at the INL generally were purged for a minimum of 1 wellbore volume; however, some wells were purged for additional time, but generally followed procedures established by the USGS qualityassurance sampling plan (Bartholomay and others, 2014). Because aquifer test data (time-drawdown) were collected during routine sampling, data were collected while the well was purging and generally terminated after routine sampling was completed. Monitor wells were located throughout the INL, but clustered near INL facilities where most of the monitoring occurs (figs. 2 and 3).

To supplement pump testing data, geophysical data along with geologic descriptions were examined for wells. Geophysical, geologic, and well construction data were examined for each well along with length of water column intervals for the ESRP aquifer. Geophysical data were used to examine borehole conditions, confirm areas of fractured and dense basalt, and confirm the location and thickness of sediment layers. Groundwater generally moves through fractured basalt and often is restricted in areas of dense basalt and within sediment layers. Identifying areas of basalt fractures, dense basalt, and sediment provides a cursory look at well productivity.

\section{Purpose and Scope}

The purpose of this study is to examine aquifer test data collected for 101 wells using an approach that examines the water-level response to pumping (discharge) at a semiconstant rate based on a linear regression equation to estimate transmissivity. The data collected were used to provide estimates of specific capacity and transmissivity for INL wells constructed within the ESRP aquifer. This report examines single-well aquifer test data collected for 101 individual wells to determine the spatial variability of transmissivity across the INL. Additionally, figures and tables are presented to show the most up-to-date well construction, geophysical data, and geologic data. Data generally were limited to five or less observations while purging the well for other sample activities. The technique used to collect aquifer test data was developed to allow field technicians time to conduct routine groundwater sampling, but still capture time-drawdown data while purging the well. Not all pumping wells were stable prior to the end of the test, but those data were noted accordingly. The pumping well data collected helped refine approximations of transmissivity based on a specific-capacity method described in Ackerman (1991). The time-drawdown data will be used to determine regional differences in transmissivity intended for groundwater model development. 

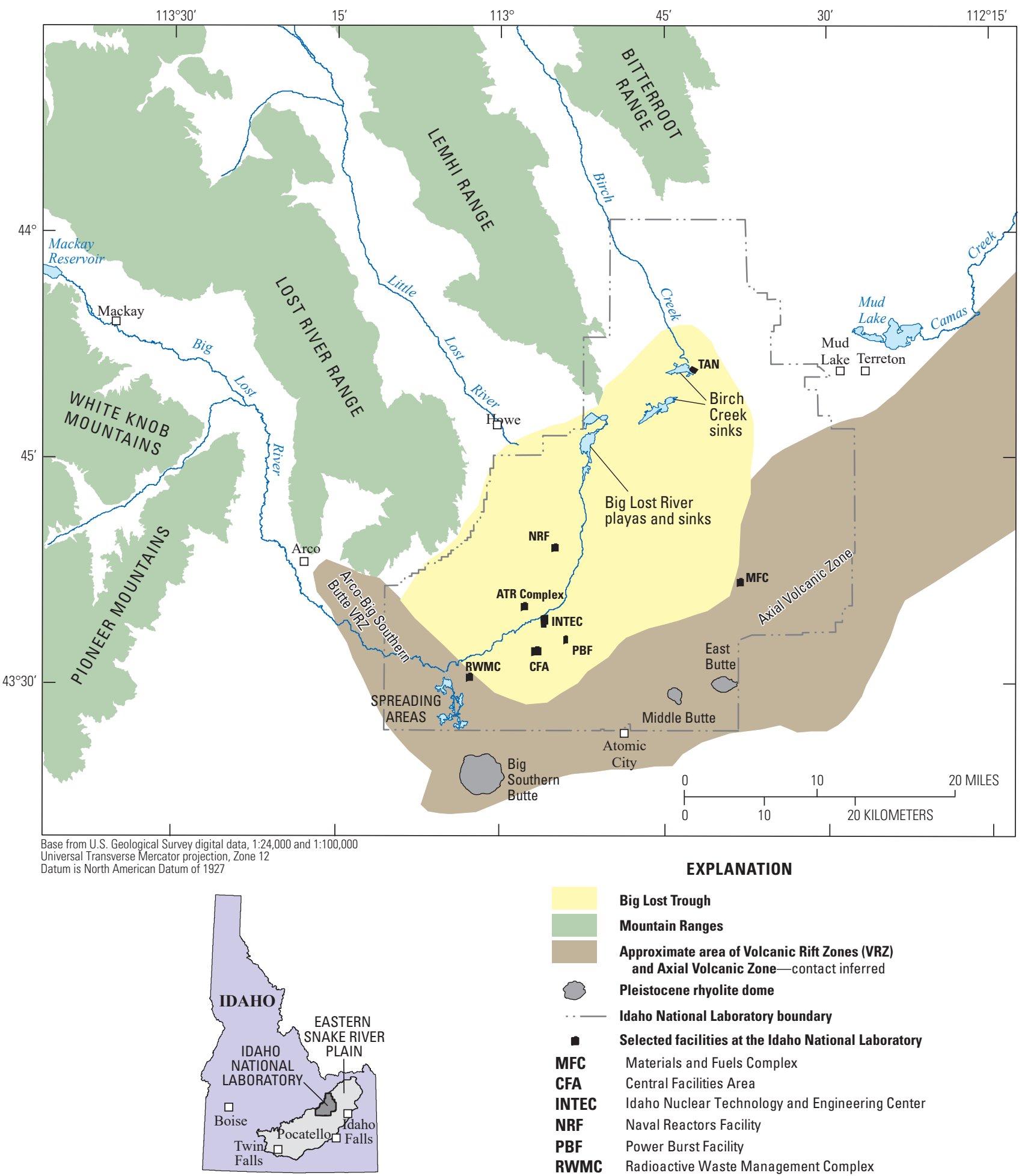

Big Lost Trough

Mountain Ranges

Approximate area of Volcanic Rift Zones (VRZ) and Axial Volcanic Zone-contact inferred Pleistocene rhyolite dome

Idaho National Laboratory boundary

Selected facilities at the Idaho National Laboratory

MFC Materials and Fuels Complex

CFA Central Facilities Area

INTEC Idaho Nuclear Technology and Engineering Center

NRF Naval Reactors Facility

PBF Power Burst Facility

RWMC Radioactive Waste Management Complex

ATR Advanced Test Reactor Complex-formerly known

Complex as Reactor Technology Complex (RTC) and Test Reactor Area (TRA)

TAN Test Area North

Figure 1. Location of selected facilities at the Idaho National Laboratory, Idaho. 


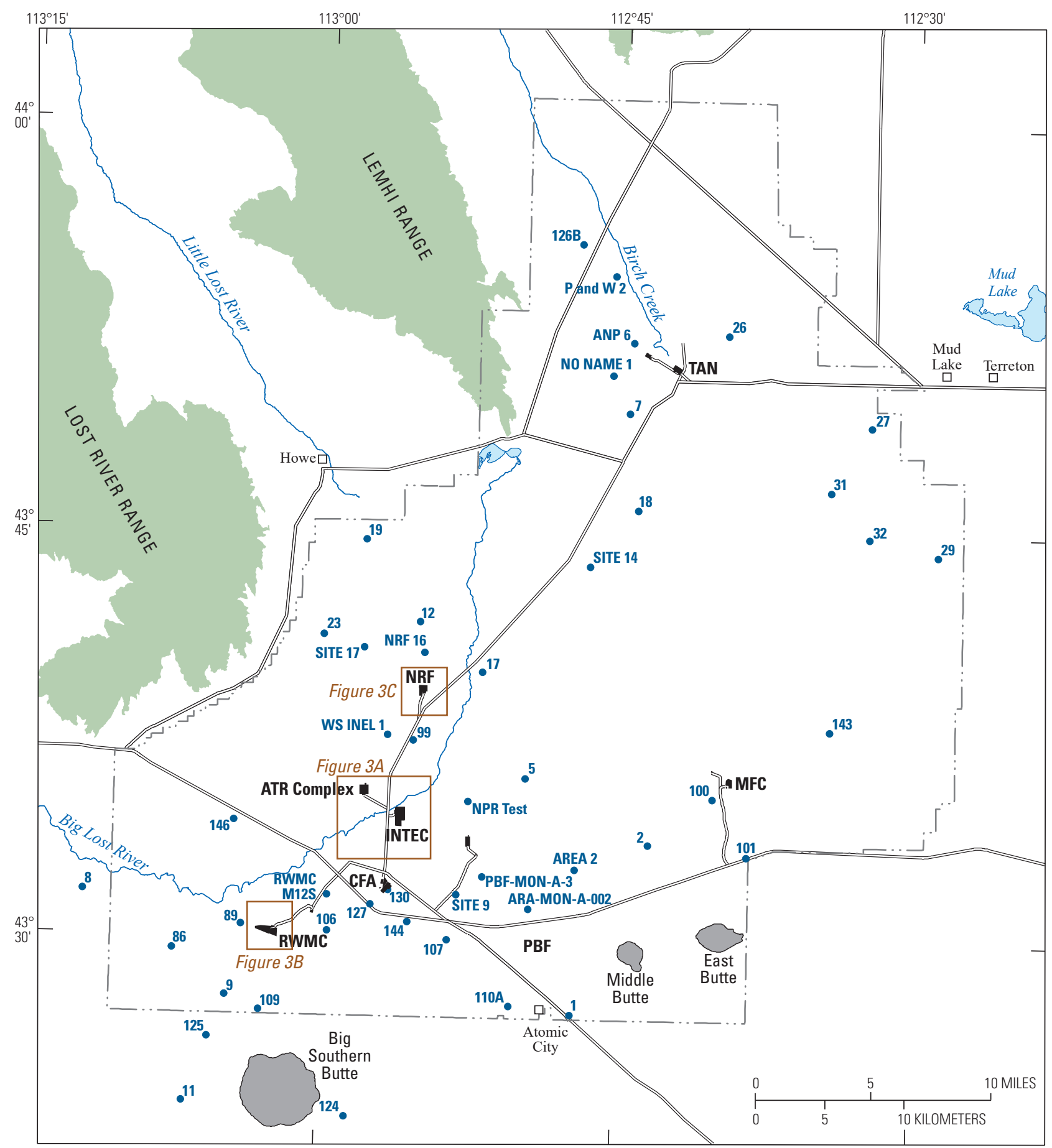

Base from U.S. Geological Survey digital data, 1:24.000 and 1:100,000 Universal Transverse Mercator projection, Zone 12

North American Datum of 1927

\section{EXPLANATION}

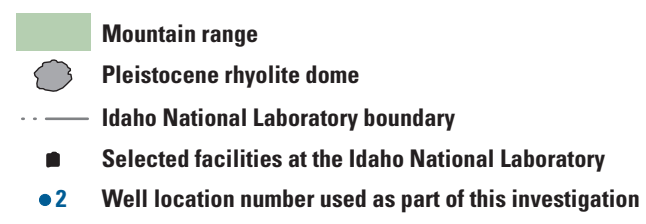

Figure 2. Location of monitor wells selected as part of this study and selected facilities at and near the Idaho National Laboratory, Idaho. See table 2 for a list of wells and well details. ATR Complex, Advanced Test Reactor Complex; CFA, Central Facilities Area; INTEC, Idaho Nuclear Technology and Engineering Center; MFC, Materials and Fuels Complex; NRF, Naval Reactors Facility; PBF, Power Burst Facility; RWMC, Radioactive Waste Management Complex; TAN, Test North Area. 


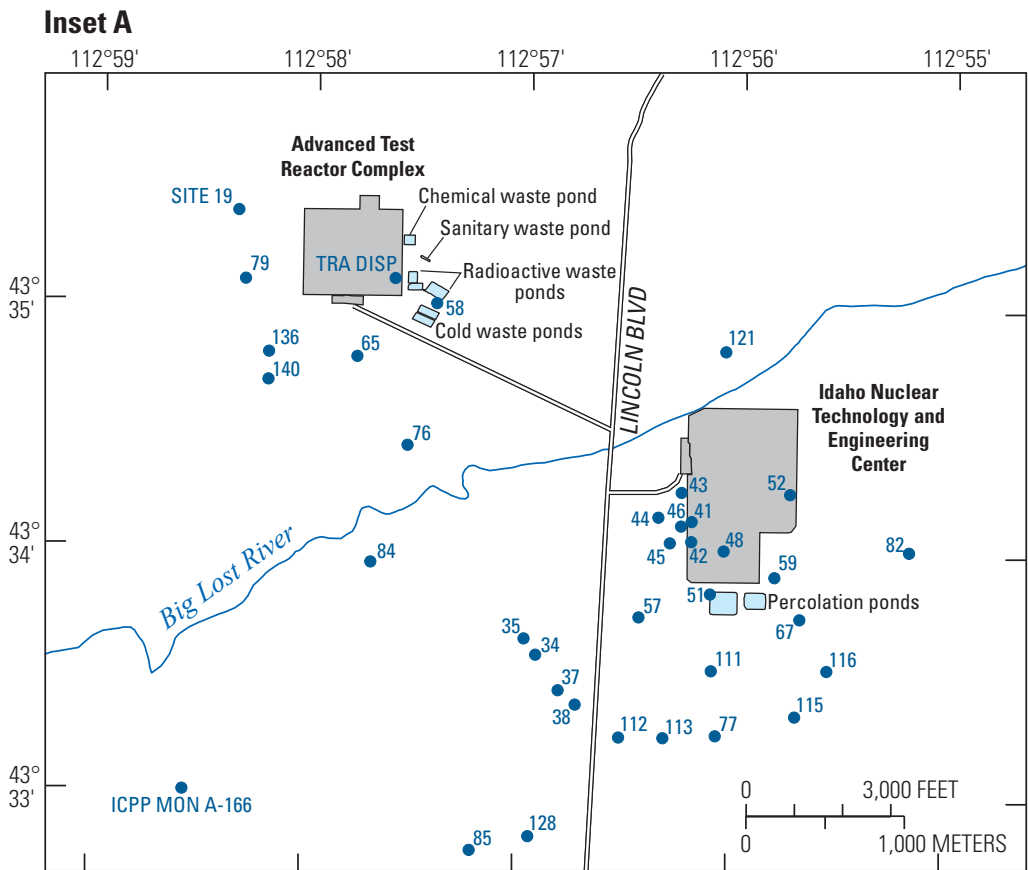

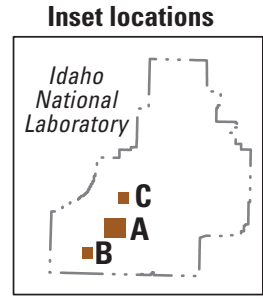

\section{EXPLANATION}

[. Selected facilities at the Idaho National Laboratory

- Well in the USGS aquifer water-level monitoring network

Local well identifier

$115 \quad$ Number only indicates USGS well number CFA LF 2-10 Local well name

\section{Inset B}

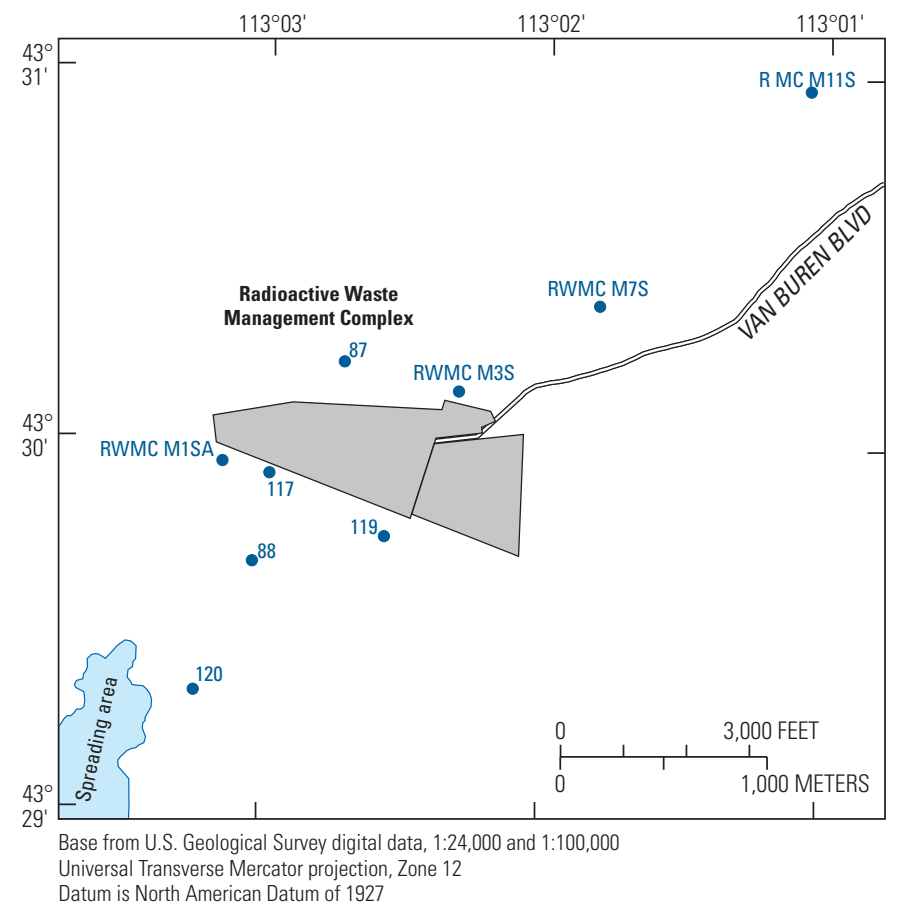

Inset C

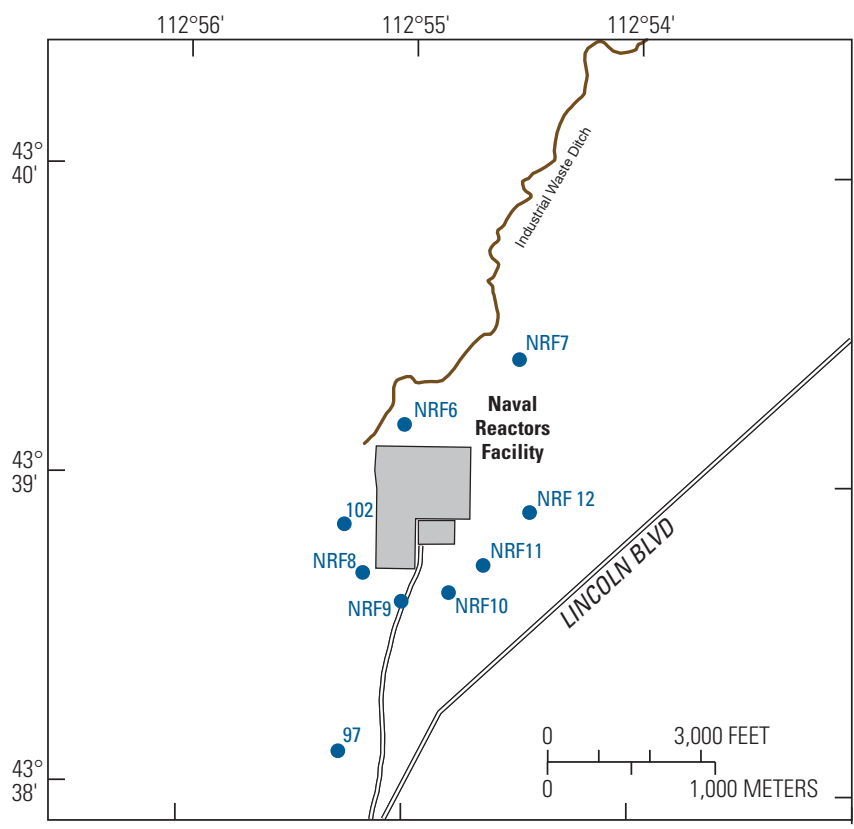

Figure 3. Location of wells and selected facilities at the Advanced Test Reactor Complex and Idaho Nuclear Technology and Engineering Center (inset A), Radioactive Waste Management Complex (inset B), and Naval Reactors Facility (inset C), Idaho National Laboratory, Idaho. 


\section{Hydrogeologic Setting}

The INL is located within the west-central part of the ESRP (fig. 1). The ESRP is a northeast-trending structural basin about $200 \mathrm{mi}$ long and 50-70 mi wide. Formation of the ESRP was caused by the passage of the North American tectonic plate over the Yellowstone Hot Spot (Pierce and Morgan, 1992). The ESRP is subject to continuing basaltic volcanism and subsidence because disruption to the crust resulted in increased heat flow (Blackwell and others, 1992) and emplacement of a dense, mid-crustal sill (Shervais and others, 2006). The subsiding ESRP basin was filled with interbedded terrestrial sediments and Pleistocene to late Pliocene basalt, 0.6-1.2 mi thick (Whitehead, 1992). The basaltic rocks and sedimentary deposits make up the ESRP aquifer.

The ESRP is composed mostly of olivine tholeiite basalt flows, which erupted as tube-fed, inflated, pahoehoe flows that make up more than 85 percent of the subsurface volume of the ESRP at the INL (Anderson and Liszewski, 1997). The distribution of basalt flows is controlled by topography, rate of effusion, and duration of eruption. Near-vent flows are thinner than distal flows, and accumulations of thin flows have a larger volume of high-conductivity zones than the same volume of thick flows (Anderson and others, 1999).

The part of the Snake River Plain aquifer that underlies the ESRP is one of the most productive aquifers in the United States (U.S. Geological Survey, 1985, p. 193). Most wells constructed within the ESRP aquifer generally yield large amounts of water owing to the highly transmissive nature of fractured interflow zones present in basalt; however, that is not the case for all wells constructed within the ESRP as this study shows. The aquifer framework results in a complex, heterogeneous, and anisotropic medium at the scale of aquifer tests; however, certain idealizations regarding homogeneity, well construction, and aquifer extent are imperative to mathematically estimate aquifer properties (Ackerman, 1991). Mapping out areas of transmissivity variation in combination with geologic characterization can help scientists better grasp controls on groundwater movement in and around facilities at the INL.

Groundwater in the ESRP aquifer generally moves from northeast to southwest, eventually discharging to springs along the Snake River downstream of Twin Falls, Idaho-about 100 mi southwest of the INL (Whitehead, 1992). Water moves through basalt fracture zones at the tops, bases, and sides of basalt flows. Infiltration of surface water, groundwater pumping, geologic conditions, and seasonal fluxes of recharge and discharge locally affect the movement of groundwater (Garabedian, 1986). Recharge to the ESRP aquifer primarily is from infiltration of applied irrigation water, streamflow, precipitation, and groundwater inflow from adjoining mountain drainage basins (Ackerman and others, 2006).
Throughout the INL, the March-May 2017 water-table altitude ranged from about 4,550 to 4,410 ft (fig. 4). Depth to water ranged from about $200 \mathrm{ft}$ below land surface (BLS) in the northern part of the INL to more than $900 \mathrm{ft}$ BLS in the southeastern part. Most groundwater moves through the upper 200-800 ft of basaltic rocks (Mann, 1986, p. 21). The estimated transmissivity for the upper part of the ESRP aquifer is $1.1-760,000 \mathrm{ft}^{2} / \mathrm{d}$, as reported by Ackerman (1991, p. 30) and Bartholomay and others (1997, table 3). The hydraulic gradient at the INL ranges from 2 to 10 feet per mile (ft/mi); the average gradient is about $4 \mathrm{ft} / \mathrm{mi}$ (fig. 4). Horizontal flow velocities of 2-20 ft/d have been calculated on the basis of the movement of various chemical and radiochemical constituents in different areas of the ESRP aquifer at the INL (Robertson and others, 1974; Mann and Beasley, 1994; Cecil and others, 2000; Busenberg and others, 2001). Localized tracer tests at the INL have shown vertical and horizontal transport rates as high as 60 and $150 \mathrm{ft} / \mathrm{d}$, respectively (Nimmo and others, 2002; Duke and others, 2007). These flow rates equate to a travel time of about 70-700 years for groundwater beneath the INL to travel to springs discharging near Twin Falls, Idaho (fig. 1).

\section{Previous Investigations}

Aquifer properties, including transmissivity and hydraulic conductivity, are discussed in a series of reports describing the INL and wastewater movement. Numerous investigations on the hydrology and geology at the INL have been conducted through INL contractors, state agencies, and the USGS. Copies of published reports for previous USGS studies at the INL are available through the web page, https://prd-wret.s3-us-west-2. amazonaws.com/assets/palladium/production/s3fs-public/ atoms/files/INL_Bibliography_2.pdf.

The most comprehensive study of the ESRP aquifer was completed as part of the USGS Regional Aquifer System Analysis program. In that study, Whitehead $(1986,1992)$, Lindholm and others (1988), and Lindholm (1996) described the regional hydrogeologic framework, hydrologic properties, and geologic controls on groundwater movement. These studies provided the regional construct for examination of the hydrologic properties and effective base of the aquifer for aquifer testing done as part of this report.

A study that examined aquifer test data at the INL for 94 individual wells was published by Ackerman (1991). Ackerman (1991) analyzed records for 183 aquifer tests, on or near the INL, for the ESRP aquifer to develop aquifer testing criteria. The methods, assumptions, and equations developed from that study were used for this study. Many of the same wells presented in the 1991 study were examined again during this investigation. Wells previously tested were compared to wells tested during this investigation to see if water-level decline and (or) changes in well conditions had resulted in changes to well productivity. 


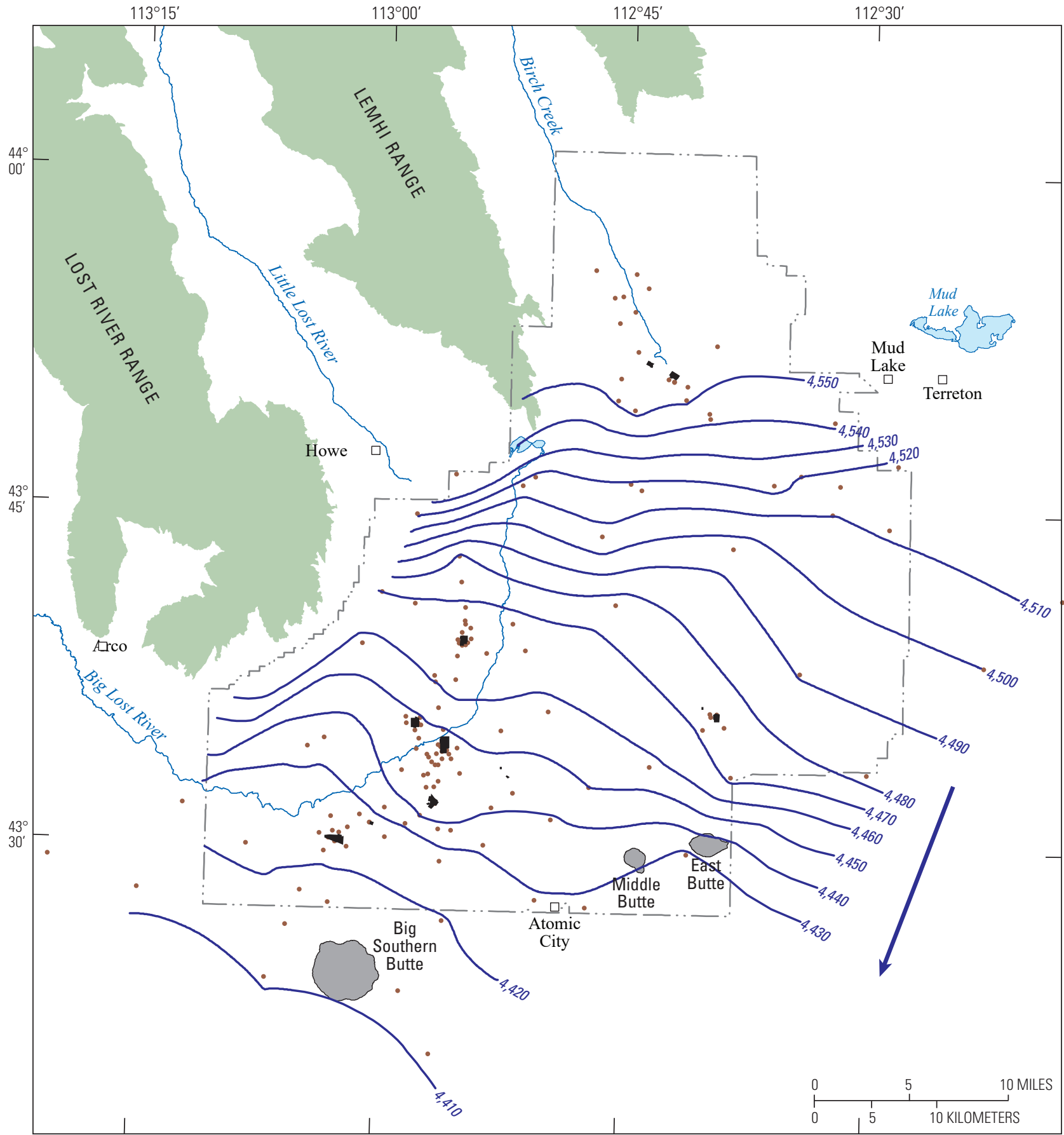

Base from U.S. Geological Survey digital data, 1:24.000 and 1:100,000 Universal Transverse Mercator projection, Zone 12 North American Datum of 1927

\section{EXPLANATION}

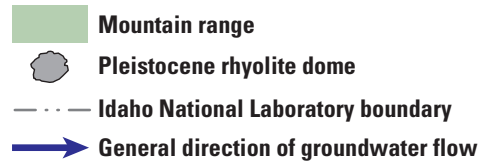

4.500 Water-table contour-Shows altitude of the water table, March-May 2017. Contour interval is 10 feet. National Geodetic Vertical Datum of 1929. Contours are approximately located.

- Selected facility at the Idaho National Laboratory

- Well location used as part of this investigation

Figure 4. Altitude of the water table in the eastern Snake River Plain aquifer at and near the Idaho National Laboratory, Idaho, March-May 2017. 
Bartholomay and others (1997) presented an analysis of water-level and water-quality data, with descriptions of the distribution and concentration of selected radiochemical and chemical constituents in groundwater at the INL. It also expanded on the information provided in the Ackerman (1991) study with additional and updated results of specific-capacity tests and transmissivity estimates for 51 wells.

A report that considered geologic controls of hydraulic conductivity in the ESRP aquifer at and near the INL was published by Anderson and others (1999). The report examined the various ranges in hydraulic conductivity resulting from 114 single-well aquifer tests. The report considered how volcanic features, such as basalt flows and dikes, can change hydraulic properties. Hydraulic conductivity was greatest in thin pahoehoe and near-vent deposits.

Hydraulic conductivity was least in flows and deposits cut by dikes. Anderson and others (1999) analyzed three broad categories of hydraulic conductivity ranging from $3.2 \times 10^{4}$ to $1.1 \times 10^{-2} \mathrm{ft} / \mathrm{d}$. These categories consider variations in basalt features in the subsurface that control hydraulic properties. The first category included the coarse basalt features that easily transmit water, including flow contacts, rubble zones, and cooling fractures of tube-fed pahoehoe flows. The second category included relatively thick, tube-fed pahoehoe flows that may be ponded in topographic depressions and thin tube-fed pahoehoe flows cut by discontinuous dikes. The third category that represented the lowest hydraulic conductivity ranges and basalt features included localized dike swarms and thick tube-fed pahoehoe flows cut by discontinuous dikes. Anderson and others (1999) also identified vent corridors, numbered 1-45, that were used to reference regions of low transmissivity identified within this report.

Twining and others $(2012,2014$, and 2016) provided completion summaries for wells USGS 136, 140, 141, TAN 2271 and TAN 2272, located near the INL Advanced Test Reactor Complex (ATR Complex) and Test Area North (TAN). These reports provided results from single-well aquifer tests that were used to estimate hydraulic properties using methods similar to those described in this report.

\section{Geophysical Data}

Geophysical data were collected from wells during construction and routine maintenance for servicing. Wireline geophysical logs were collected using Century Geophysical Corporation $^{\mathrm{TM}}$ logging equipment, and the resulting data files were processed using WellCAD ${ }^{\mathrm{TM}}$ analytical software. Geophysical data are available upon request through the INL Project Office or logs can be obtained through USGS GeoLog Locator, by visiting the web page, https://webapps.usgs.gov/ GeoLogLocator/\#!/.
Geophysical data are presented with well construction and general lithology for each well (appendix 1). Basic hydrogeologic features for individual wells are described along with a composite of natural gamma, neutron, gammagamma dual density, and acoustic televiewer data (when available) for the section of well starting near the top of the aquifer through to the bottom of the well (see example in fig. 5). Some well diagrams include acoustic data, but these data are limited to the most recently drilled wells. Geophysical data, aquifer test data, and basic geology for wells are described in the "Comments" sections of appendix 1 geophysical logs.

Geophysical data were used to support aquifer test data along with individual well construction information to support well data. Aquifer test data, when used in combination with geophysical and well construction data, help support hydraulic property estimates. Geophysical data were used to support changes in geology and the general amount of fractured basalt; well construction information was used to show how a well is designed and (or) screened.

\section{Natural Gamma Logs}

Bulk natural gamma logs record gamma radiation emitted by naturally occurring radioisotopes, including potassium- 40 and the daughter products of uranium and thorium (Schlumberger, 1972), surrounding the wellbore. The natural gamma detector measures total gamma radiation without distinguishing between individual contributions of the various isotopes. Increases in gamma-ray emissions typically are observed in clay, feldspar-rich sand and gravel, and granite; therefore, natural gamma logs primarily are used to identify sedimentary layers penetrated by wellbores (fig. 5), but they also can be used to distinguish between rock units that indicate different amounts of potassium-40. For example, basalt and rhyolite show a measurable change in natural gamma, where rhyolite shows elevated natural gamma over basalt. Natural gamma logs were used to help identify and confirm the location and thickness of sediment layers in wellbores when describing the general lithology in appendix 1.

\section{Neutron Logs}

Neutron measurements are a general indicator of hydrogen content. The neutron tool used by the USGS INL Project Office is a compensated neutron logging tool that has an americium/beryllium neutron source and a Helium-3 detector. This log measures the rate of decrease of neutron density with distance from a source. The rate of decrease, represented by the ratio of the near-to-far count rates, primarily is owing to the hydrogen content of the formation (Crain, 2018). Because water is the primary source of hydrogen, a compensated neutron log was used to indicate changes to saturated porosity. 


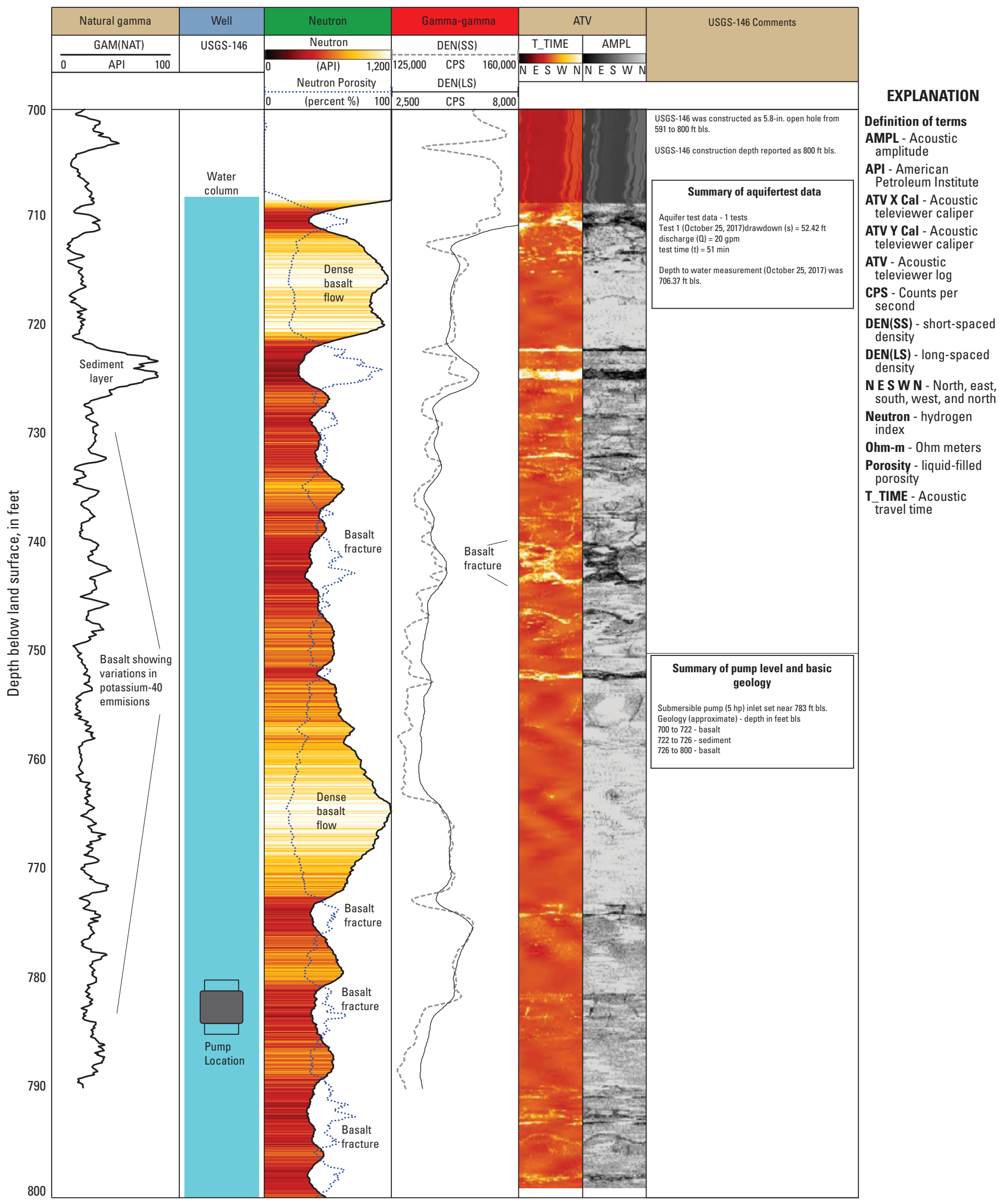

Figure 5. Geophysical logs of data for well USGS 146, similar to wells in appendix 1 files, and showing natural gamma, well completion, neutron, gamma-gamma density, acoustic televiewer, and comments at the Idaho National Laboratory, Idaho. 
USGS INL policy prohibits source logging in uncased wellbores because of the risk of losing a logging source. Neutron logs are presented for wells through casing and (or) after drilling and before the drill rod is removed, ideally in a cored borehole after total depth is achieved. Neutron logs are not available for all wells in digital format; however, the neutron logs that are available electronically were included in appendix 1 . To help identify water-producing zones, a color gradient, ranging from red (high hydrogen content, high porosity) to white (low hydrogen content, low porosity), was applied to neutron representations included in appendix 1 (fig. 5). Based on basalt-hydrogen correlations, neutron logs suggest areas of fractured and vesicular basalt, indicative of more productive water-producing zones in contrast to less productive areas of dense basalt where the wellbore is not likely to produce much water. Neutron porosity values are approximated based on neutron response; however, these values are not calibrated to basalt rock and only indicate relative change (fig. 5).

\section{Gamma-Gamma Logs}

The principle behind gamma-gamma logging is the detection of Compton-scattered gamma rays that originate from a small radioactive source. The intensity of the gamma radiation reflected back to the probe primarily is a function of electron density of the media after it is backscattered or absorbed by borehole fluid, well casing, and surrounding media. The electron density of the surrounding media is directly related to the bulk density of the material. The type of density probe used for this investigation is the omnidirectional, dual detector, sonde that responds to density variation in counts per second. The difference in count rates observed at the two differently spaced detectors-DEN(SS) and DEN(LS); (fig. 5) - show the effects of the borehole fluid, well casing, and surrounding media. Gamma-gamma density logs were collected in cased wellbores and used synergistically with natural gamma and neutron logs to suggest change in rock density (fig. 5).

\section{Acoustic Televiewer Logs}

Acoustic televiewer (ATV) logs show high-resolution images of the borehole wall by rotating a transducer that transmits digital ultrasonic pulses. The acoustic travel time and acoustic amplitude of the reflected acoustic signal are recorded as photograph-like images (fig. 5). The image data are captured once the probe enters the saturated zone and can be run within water or light drilling mud filled borehole(s). Lithologic changes, foliations, bedding, and fractures may be detected even when there is no change in the borehole diameter if there is sufficient acoustic contrast (Williams and Johnson, 2004). In general, increased transit time (lighter colors) and decreased amplitude (darker colors) represent fracture zones; decreased transit time (darker colors) and increased amplitude (lighter colors) represent homogenous rock or sediment; and slight changes in color can be interpreted as changes in density. The USGS uses the ATV log data in conjunction with borehole core and other logs to verify the location of fractures, and fracture density, thickness, and orientation; and to show sediment zones (fig. 5).

\section{Description of Wells}

The USGS maintains an extensive monitoring network of wells throughout the INL to characterize the occurrence, movement, and quality of water in the ESRP aquifer. This network includes wells constructed using various methods and completed to various depths. Well USGS 1 was one of the first monitor well sites at the INL that is still in use today; it was drilled in 1949 (fig. 2). Well construction varies from site to site, but generally includes one or a combination of the following: (1) perforated casing, (2) combination of perforated casing and blank casing, (3) continuous-slot screen (well screen), and (4) open-hole construction (table 1; appendix 1).

Well loss was not examined during this study; however, it represents the head lost to friction as water passes through the well screen. Decreased well productivity can result in larger drawdowns that do not necessarily indicate the characteristic aquifer. Therefore, well construction is important to consider when looking at well productivity. The age, material used, type of well completion, well development, and well diameter can influence well productivity. Decreased well productivity can result from scale or rust along perforated intervals and has been observed in USGS borehole video(s) taken in older wells constructed with perforated casing and (or) well screens. Wells constructed with perforated steel casing and (or) well screens can lose production capacity with time if mineral precipitation occurs. To further complicate matters, wells constructed with perforated steel casing can undergo accelerated galvanic corrosion from setting a stainless-steel submersible pump in a section of steel casing. This corrosion eventually can lead to reduced well efficiency over time. Wells constructed as open hole generally do not have well efficiency problems. About 50 percent of the wells included in this study are constructed as open hole, 26 percent are constructed with perforated casing, and 24 percent are constructed with well screen (table 1 and appendix 1). The ESRP aquifer is well suited for openhole monitor wells where unconsolidated sediment is not a concern. However, wells constructed in areas were sediment is prevalent generally require well screens and (or) blank casing. 


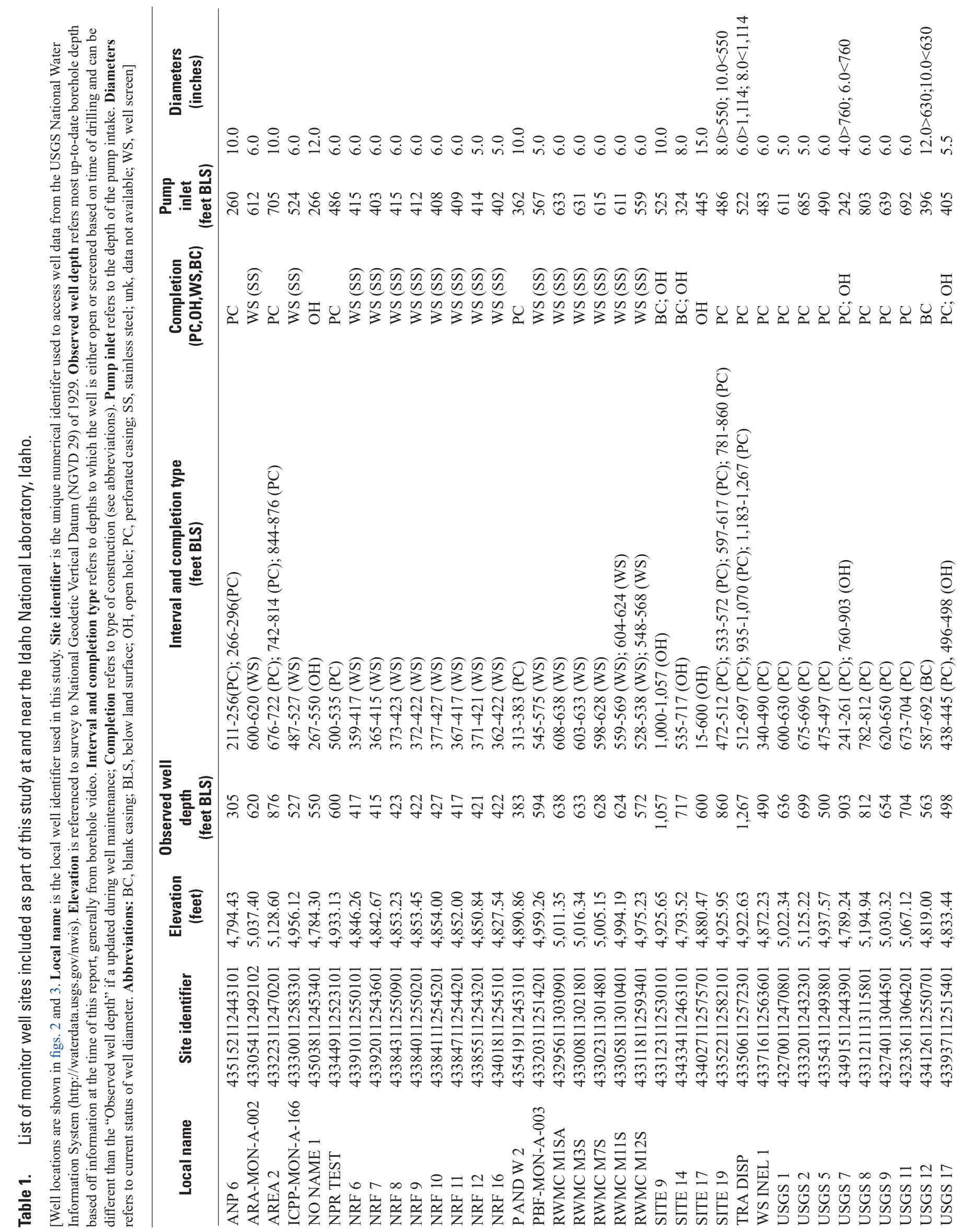




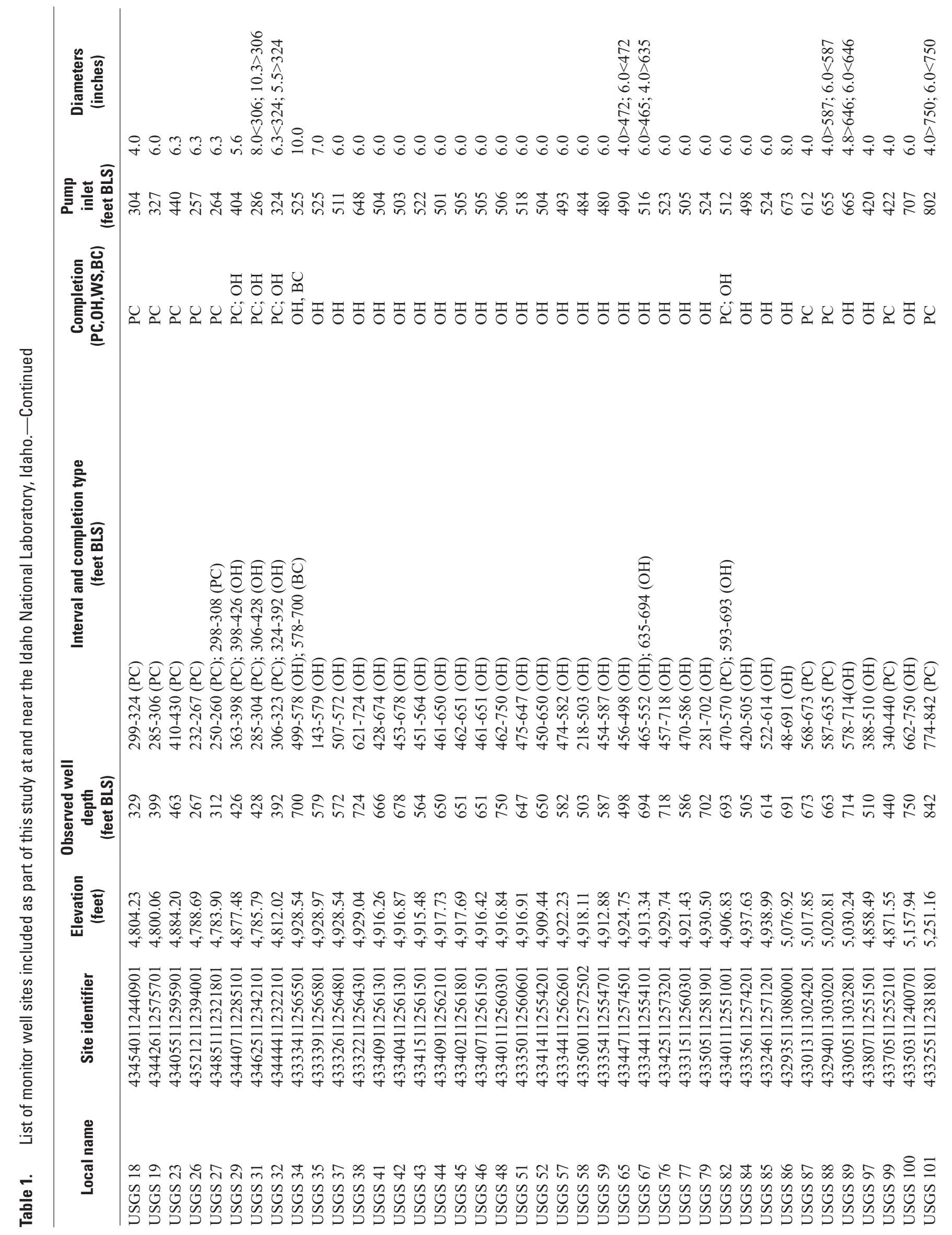




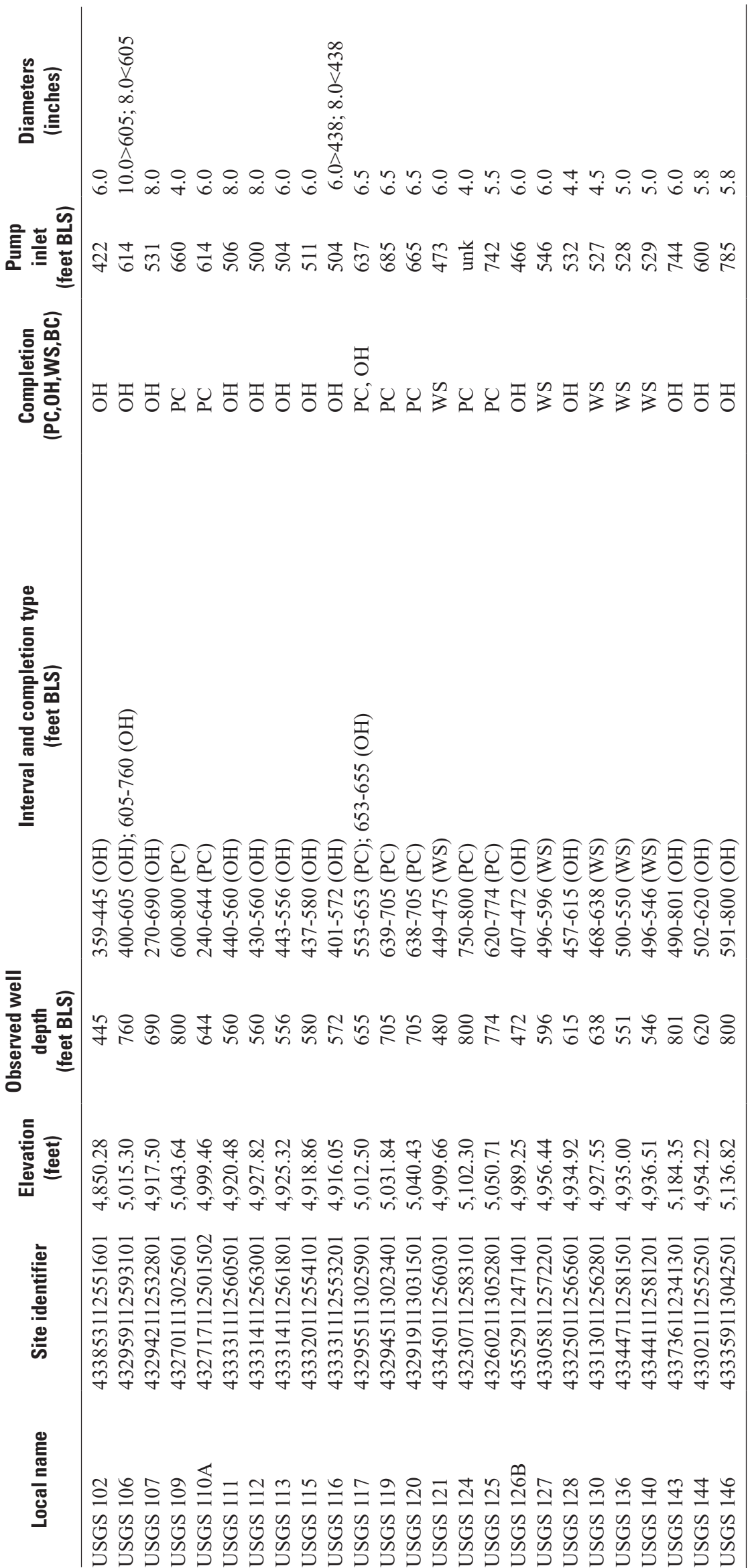


Wells examined as part of this study range in diameter from 4 to 15 in., with water column height (open interval) ranging from 12 to $790 \mathrm{ft}$ (tables 1 and 2). Each well was equipped with a dedicated submersible pump(s), generally 5-horsepower, and dedicated water-level measurement lines. Pump discharge lines generally were 1.25 in. and dedicated water-level measurement lines generally were $1.00 \mathrm{in}$. Submersible pump inlet depth and well depth are listed in table 1. Submersible pump inlet(s) generally were placed near water-producing fracture(s) when possible. Dedicated waterlevel measurement lines and calibrated electric tapes (e-tapes) were used to take water-level measurements in response to the stressing of the aquifer through pumping.

\section{Aquifer Test Methods and Analysis}

Single-well aquifer tests were completed for 101 well sites during April, May, and October 2017; however, some wells required retesting, which was done during 2018 (table 2 and appendix 2). The hydraulic property estimates were recorded in the USGS Groundwater Site Inventory database, and data collected during the aquifer test(s) were archived in the USGS Idaho Water Science Center Test Archive after review.

Methods for analyzing aquifer-test data were developed using simplified assumptions. When these assumptions are not met, the ability to interpret the data is limited (Ackerman, 1991). Problems in the execution of these aquifer tests that limit the ability to interpret data are as follows (modified from Ackerman, 1991):

1. Limited test time and non-steady discharge rates;

2. Limited discharge rate for some wells in high transmissivity areas;

3. Wellbore storage effects;

4. Decrease in saturated thickness with pumping;

5. Well construction problems related to sediment infilling and (or) plugged casing or screened sections;

6. Filling and draining of deep pump columns in wells;

7. Lack of water-level trends and barometric fluctuations and efficiency;

8. No observation well data to define the effects of partial penetration, release of water from storage, delayed watertable response, and anisotropy; and

9. Insufficient early- or late-time observations of drawdown to fully use an applicable method of interpretation.

Aquifer testing was done at the same time as scheduled groundwater sampling. Although aquifer test conditions are not ideal, the time-drawdown data collected allow for approximating specific capacity and transmissivity based on the average pumping rate and measured drawdown for individual well(s). Aquifer test time(s) ranged from 10 to 160 minutes (table 2) but generally were terminated after purging a single wellbore volume and after completion of sample collection. Under some circumstances, wells had not reached steady state when the test was terminated.

During review of the data, we observed that about 14 percent of wells were not at steady state when the pump was turned off (appendix 2). An individual well was determined to be at steady state when the water-level response to pumping was no longer changing by plus or minus $( \pm) 0.02 \mathrm{ft}$ between measurements. Furthermore, about 23 percent of wells had an immediate water-level decline followed by some waterlevel recovery later in the test. For example, well USGS $125 \mathrm{had}$ an initial drawdown of 8.65 and $6.16 \mathrm{ft}$ at 1 and 3 minutes, respectively; however, at 5 minutes, drawdown was mostly stabilized near $5.74 \mathrm{ft}$ (appendix 2). Well USGS 125 was constructed with 5 -in. perforated casing (appendix 1), so the initial drawdown could be related to wellbore storage, alternating discharge, and (or) plugged perforations. About 65 percent of the wells that had this type of response where constructed with wire-wrap well screen or slotted casing (table 1, appendix 2). Wells, well depth, interval and completion type, pump inlet depth, and well diameters are summarized in table 1. Copies of aquifer test field records are provided in appendix 2 .

Aquifer test data were used to calculate specific capacity and transmissivity for each well after data was reviewed. Specific capacity is a measure of the well yield per unit of drawdown, expressed in gallons per minute per foot of drawdown. Specific capacity is obtained by dividing the pumping rate by the drawdown for a specific pumping period. Transmissivity is defined as the rate at which water of prevailing kinematic viscosity is transmitted through a unit width of the aquifer under a unit hydraulic gradient (Lohman, 1972). Transmissivity estimates yield valuable data when assessing the capacity of an aquifer to transmit water through areas of the ESRP aquifer. Transmissivity is expressed in feet squared per day and was estimated from specific-capacity data. The method used to approximate transmissivity is referred to as the specific-capacity method, as defined in Ackerman (1991). The specific-capacity method has less certainty when compared to other aquifer-test methods; however, given the limited data collected and short test time allotted for sampling, this was the most appropriate analysis method that could be consistently applied.

\section{Aquifer-Test Methods}

A simplified approach was developed to complete aquifer testing. This approach involved pumping well(s) at constant discharge rates $(Q)$ while measuring water-level change $(\Delta s)$ in response to pumping using a calibrated e-tape. Barometric data were not collected and were considered to have minimal effect on water-level response because of the short duration of the aquifer tests (table 2). 


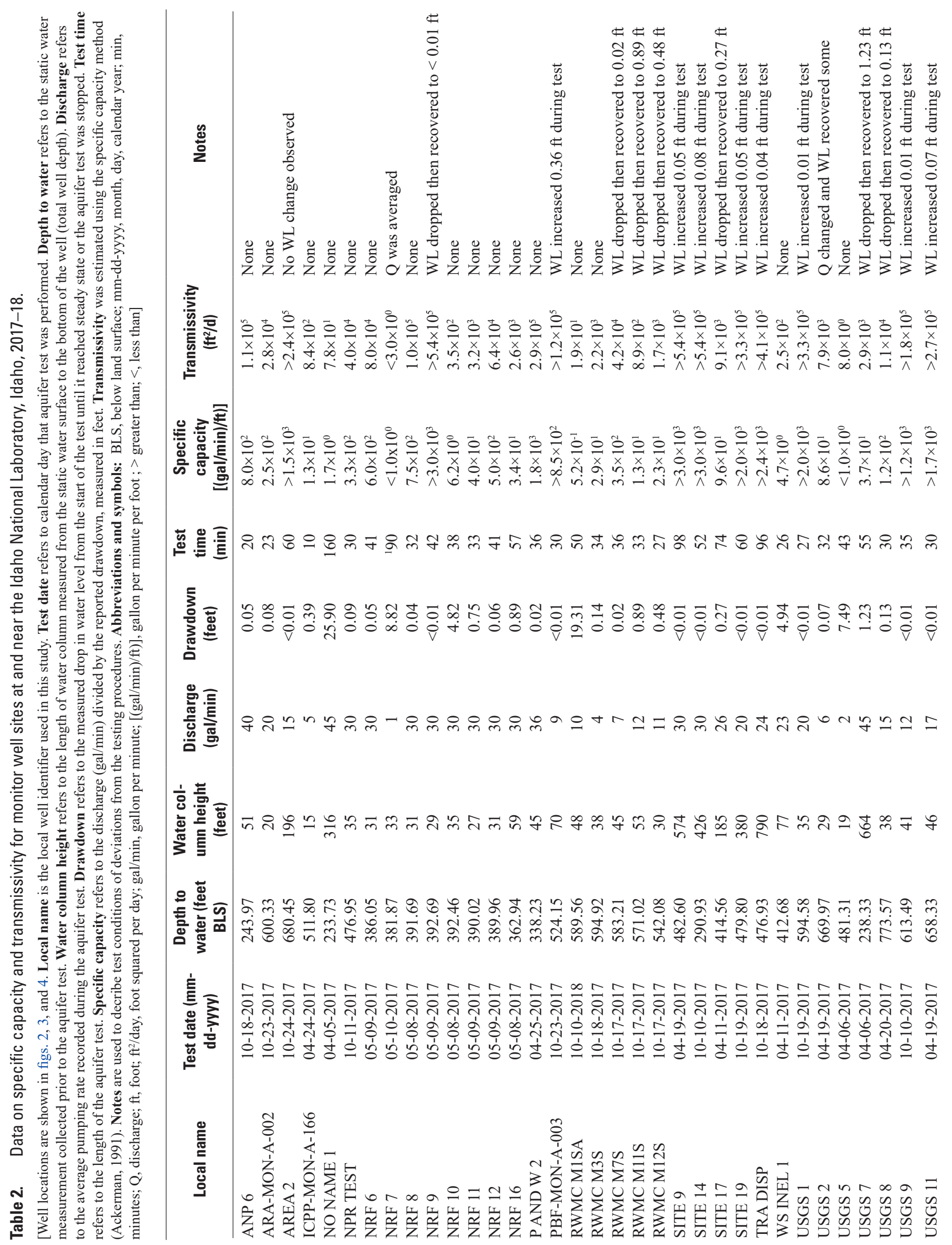




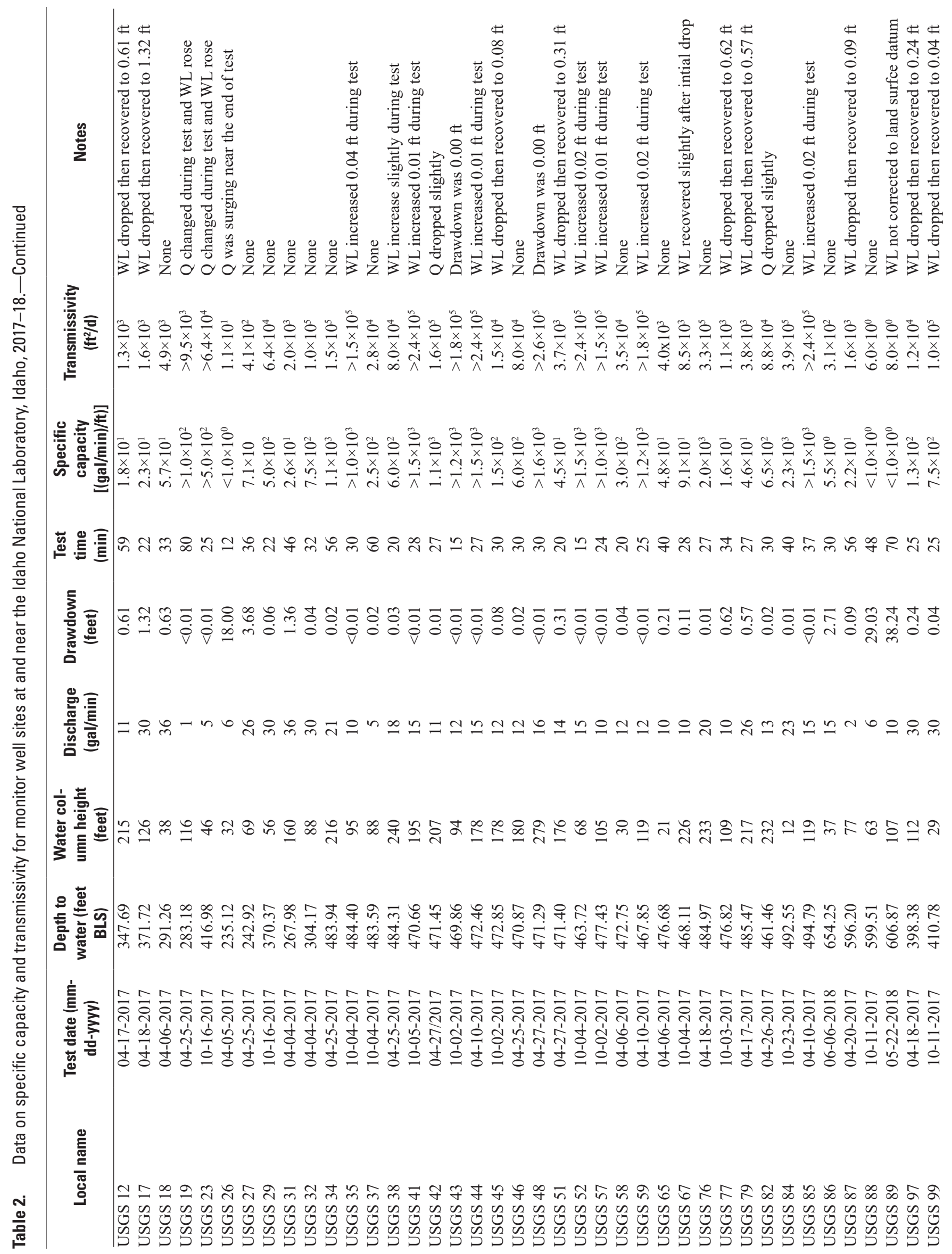




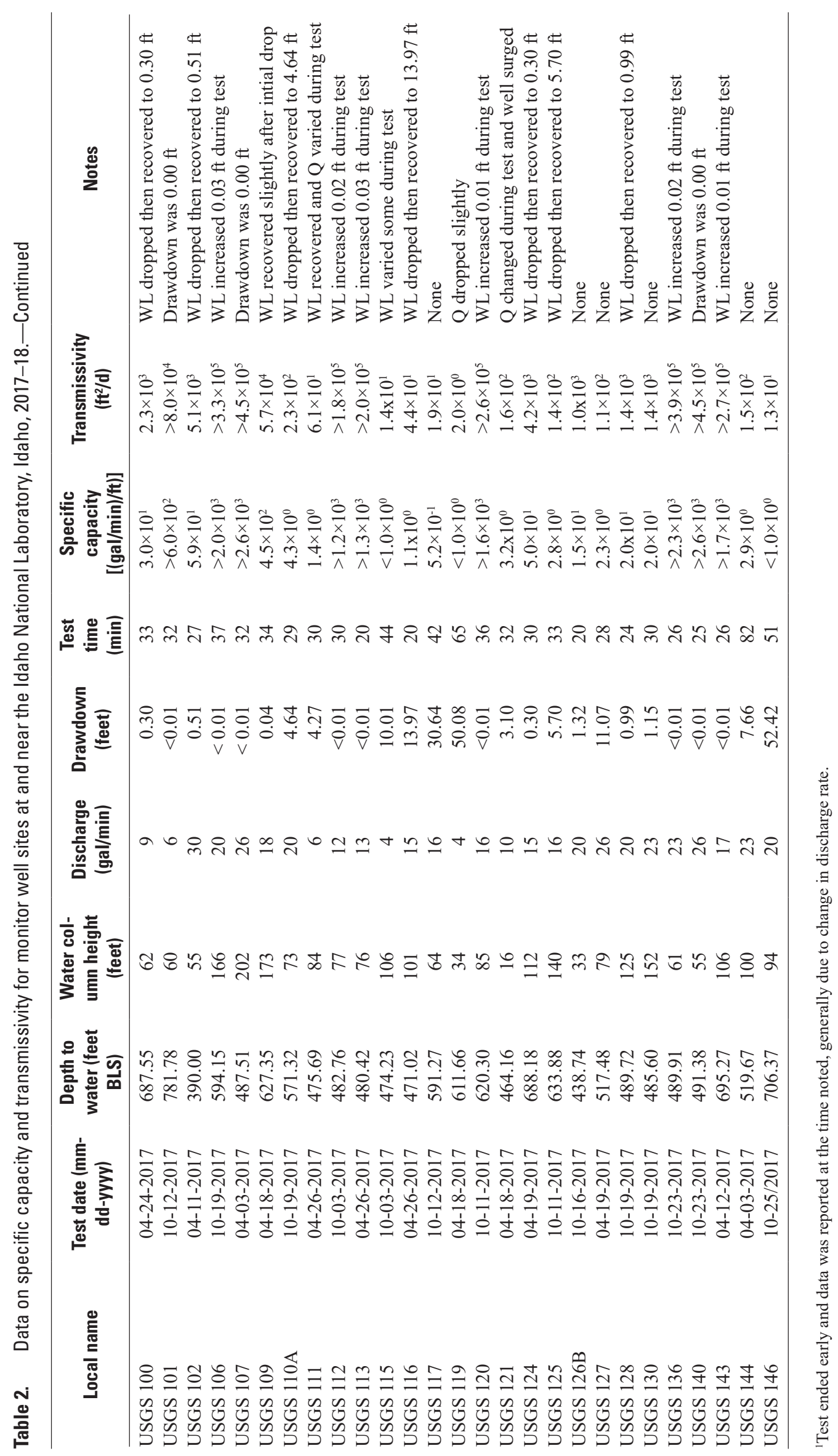


The aquifer test approach involved collecting a static water level prior to turning on the pump; afterwards, water level(s) were taken at semi-frequent intervals once groundwater began discharging to land surface. Water-level data were collected using a calibrated e-tape lowered down a dedicated water-level measurement line, separate from the pump discharge line (fig. 6). The discretion of the person doing the sampling mostly determined how frequently the water-level measurements were collected; however, the sampling team was advised to take several water-level measurements during the early stages of the aquifer test and a water-level measurement prior to shutting off the pump. The last water-level measurement prior to turning off the pump generally was used to estimate hydraulic properties.

Discharge rate(s) were measured using a 3-gallon bucket and stopwatch. Discharge generally was measured at the start and at the end of the aquifer test. Additional discharge measurements were taken as time permitted, or if the discharge rate seemed to change during the test. Problems encountered during the test were noted on the field sheets (appendix 2).

Aquifer test time was largely dependent on purge time prior to well sampling and computed from the water column height and well diameter (table 2). Wells were purged for a minimum of 1 wellbore volume, based on current sample protocol outlined in Bartholomay and others (2014). Drawdown data were not collected from nearby wells (observation wells); additionally, recovery data were not collected after the pump was shut off.

\section{Analysis of Aquifer-Test Data}

Results from single-well aquifer tests were used to calculate hydraulic properties of specific capacity and transmissivity for 101 wells in and near INL (table 2). Discharge rates $(Q)$ during testing ranged from 1 to $45 \mathrm{gal} /$ min, water-level change $(\Delta \mathrm{s})$ ranged from $<0.01$ to $52.42 \mathrm{ft}$ (USGS 146), and length of aquifer test(s) for wells ranged from 10 to 160 minutes (table 2). Data from 30 wells indicated that water-levels during pumping were $<0.01 \mathrm{ft}$ and (or) rose slightly during testing (appendix 2). In wells that had water levels of $<0.01 \mathrm{ft}$, drawdown was approximated at $0.01 \mathrm{ft}$ to compute estimates of specific capacity and transmissivity and were noted with a greater than symbol (>) in table 2.

During testing, attempts were made to keep discharge rates constant throughout the test. This was done using a control box that sends power to the pump and noting the power frequency. On nine occasions, the discharge rate could not be held constant during aquifer testing. For those nine events, discharge rate was averaged and reported under notes in table 2. The field sheets provided in appendix 2 report the discharge variation, if any. The discharge rate factors heavily into the computation of specific capacity, so discharge rate was reported conservatively.

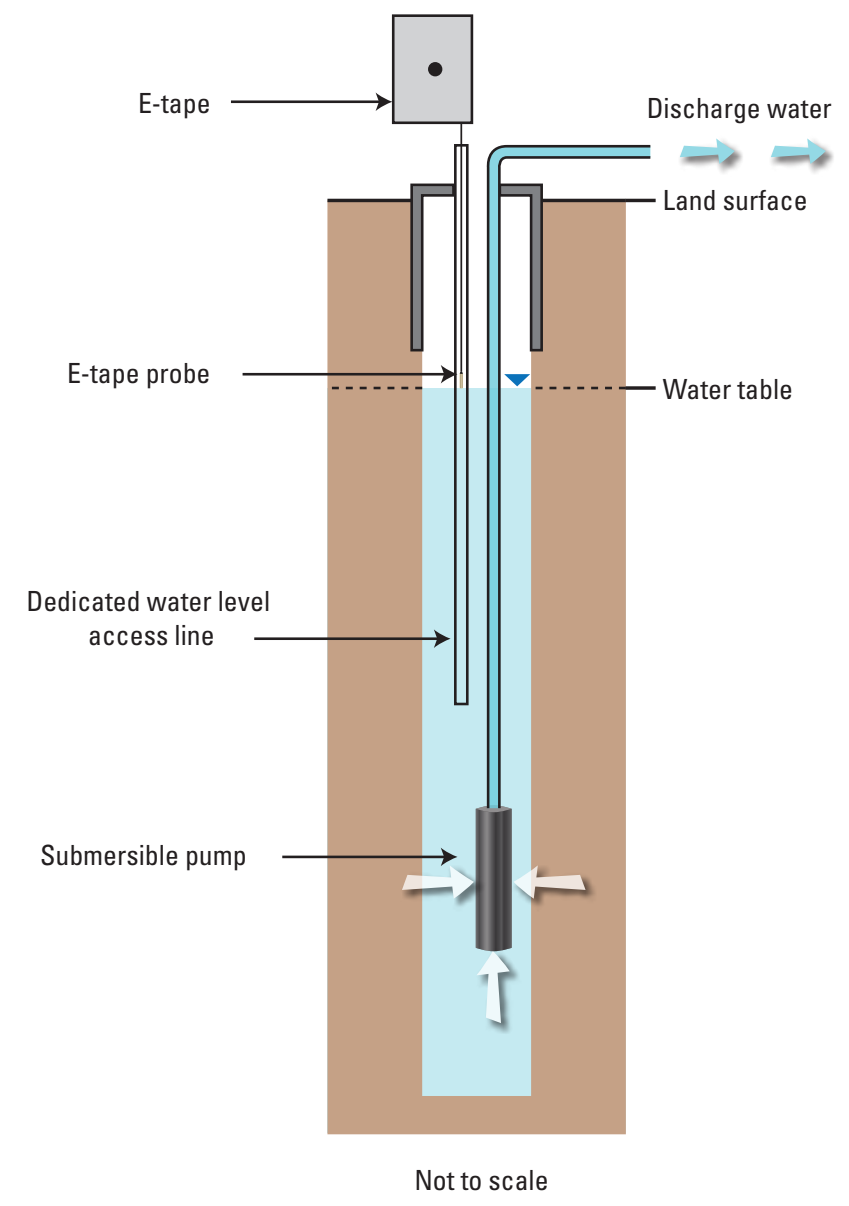

Figure 6. Configuration of wells, submersible pump, and calibrated e-tape for wells included in this study at and near the Idaho National Laboratory, Idaho.

All 101 single-well aquifer tests were analyzed using the specific-capacity method to approximate transmissivity (Ackerman, 1991). This method is based on a linear regression equation to estimate transmissivity near the well from specific capacity. The specific-capacity method was selected because of the limited amount of data collected during aquifer testing, usually five measurements or less (appendix 2). Most aquifer test analysis methods require numerous waterlevel measurements to create a drawdown curve that can be matched to a type curve(s) to estimate transmissivity; however, the specific-capacity method does not require the same level of data collection and can be used with limited data. The disadvantage of the specific-capacity method is that data analysis may only represent the transmissivity immediately near the well (Ackerman, 1991) and it is heavily dependent on the meausred discharge. Many wells could not be stressed enough to produce a measurable drawdown, as was the case for 30 wells (table 2). The discharge rate also was infrequently measured; therefore, slight variation in discharge can overestimate or underestimate hydraulic properties. 
Specific capacity $(S C)$ is an expression of the productivity of a well commonly expressed as the ratio of the discharge rate $(Q)$ in gallons per minute to the total measured drawdown $(s)$ in feet. The specific-capacity method estimates transmissivity (T) through the use of the following equation(s) (Ackerman, 1991):

$$
\begin{gathered}
S C=\left(\frac{Q}{S}\right) \\
T=(S C)^{1.1853} \times 40.62=\left(\frac{Q}{S}\right)^{1.1853} \times 40.62
\end{gathered}
$$

where

$$
\begin{gathered}
T \quad \begin{array}{c}
\text { is the transmissivity in feet squared per day } \\
\left(\mathrm{ft}^{2} / \mathrm{d}\right),
\end{array} \\
S C \quad \begin{array}{c}
\text { is the specific capacity in gallons per minute } \\
\text { per foot ([gal/min]/ft), }
\end{array} \\
\begin{array}{c}
\text { is the discharge rate in gallons per minute } \\
\text { ( } \mathrm{gal} / \mathrm{min}), \text { and }
\end{array} \\
S \quad \text { is the drawdown in feet (ft). }
\end{gathered}
$$

The drawdown in the pumped well, $s$, at any given time, $t$, is determined by subtracting the water level $\Psi_{(\mathrm{t})}$ at time $t$ from the initial static water level prior to pumping, $\Psi_{0}$. Drawdown as a function of time is expressed as:

$$
s(t)=\psi_{0}-\psi(t)
$$

The specific-capacity method was applied to the aquifer test data shown in appendix 2 . The specific-capacity data ranged from $<1.0$ to $>3.0 \times 10^{3}[(\mathrm{gal} / \mathrm{min}) / \mathrm{ft}]$; transmissivity data ranged from 2.0 to $>5.4 \times 10^{5}\left(\mathrm{ft}^{2} / \mathrm{d}\right)$ (table 2). Example calculations of these parameters are as follows for well ANP 6 (table 2):

$$
\begin{aligned}
& S C=\left(\frac{Q}{s}\right)=\frac{40 \mathrm{gal} / \mathrm{min}}{0.05 \mathrm{ft}}=800([\mathrm{gal} / \mathrm{min}] / \mathrm{ft}) \\
& T=(S C)^{1.1853} \times 40.62=800([\mathrm{gal} / \mathrm{min}] / \mathrm{ft})^{1.1853} \\
& \times 40.62=1.1 \times 10^{5}\left(\mathrm{ft}^{2} / \mathrm{d}\right)
\end{aligned}
$$

Well ANP 6 was pumped at a discharge rate of $40 \mathrm{gal} / \mathrm{min}$ for a length of 20 minutes (appendix 2). During that time, well ANP 6 recorded $0.05 \mathrm{ft}$ of drawdown at the end of the test. The discharge rate was constant during the test and the drawdown observed was immediate, declining $0.05 \mathrm{ft}$ after the first minute. Many of the tests conducted for the ESRP aquifer show similar results (appendix 2). For most of the wells, it is impossible to fit a type curve to the test data so the specific-capacity method was determined to be the appropriate analytical method to use. Furthermore, specific capacity provided a consistent and quick way to calculate hydraulic properties for all 101 wells that had aquifer test data available.

\section{Quality Assurance}

USGS INL Project standards for collecting groundwater levels and water-quality samples from within a well are documented in Bartholomay and others (2014); and U.S. Geological Survey [various dates, book 9]; however, standards for aquifer testing are variable. The following approach was used to evaluate the accuracy and precision of aquifer test data reported in this study. Aquifer test data used to estimate specific capacity and transmissivity, defined by equations 1 and 2, is dependent on two variables: (1) measured discharge $(Q)$ from the well; and (2) the change in water level $(\Delta s)$ as the aquifer test occurs.

The discharge measurement was done using a bucket and stopwatch approach. This involves capturing pumped groundwater in a 3-gallon bucket while measuring the time it takes to fill the bucket between graduated marks. Once the bucket fills to the 3 -gallon graduated mark, the time is recorded and used to compute the discharge rate from the well. Under ideal testing conditions, a digital or mechanical flow meter would be used to give a better approximation of discharge; however, this was not done under this testing scenario. The bucket and stopwatch approach generally were repeated until discharge stabilized. The uncertainty with this type of discharge measurement is considered relatively small; however, uncertainty cannot be quantified using the data collected. The pump output was held constant through a variable speed control box. For most tests, discharge measurements were collected as time permitted and at the discretion of the field personnel. We recognize that there is human measurement error associated with using a mechanical stopwatch that could not be accounted for.

The water levels were collected using a calibrated e-tape. The calibrated e-tape(s) used during aquifer testing are numbered to have a calibration rating associated with each e-tape. The calibration data are computed in 50-ft increments over the range of the tape, with calibration verified at least annually. During testing, the calibrated e-tape was lowered down the dedicated water-level measurement line to collect a static water level before the testing started (fig. 6). The calibrated e-tape probe was left just above the static level when the pump is turned on. Once the pump was turned on, the water-level change was reported on the aquifer test sheet along with the associated time (appendix 2). The assumed accuracy of the water-level measurement was reported as $\pm 0.01 \mathrm{ft}$. 
Barometric pressure data were not collected during these aquifer tests. Wells that have a minimal water-level response ( $\pm 0.01 \mathrm{ft}$ ) are thought to be most affected by barometric change. Based on other aquifer tests done at the INL, where barometric pressure was considered, change in barometric pressure would mostly affect wells with minimal drawdowns (Twining and others, 2012, 2014, and 2016). Additionally, based on average aquifer test lengths of less than 40 minutes (table 2), changes in barometric pressure are believed to have minimal influence on the results.

\section{Review of Well Productivity}

Change to well productivity was examined using a subset of 65 wells (table 3). The data collected during this investigation were compared to data presented in previous investigations (table 1 from Ackerman, 1991; and table 2 from Bartholomay and others, 1997). If duplicate data were available for previous investigations, the data from Bartholomay and others (1997) were used because individual well test(s) were generally done under similar conditions.

Discharge and drawdown data were used to evaluate changes to individual well productivity using current (2017) and previously conducted tests (table 3 ). Of the 65 individual wells, change in drawdown between testing periods exceeded 1 foot at 12 wells (table 3 ). Over the 30 -year period, 83 percent of wells show similar drawdown and discharge conditions, whereas changes to productivity were observed in 17 percent of the wells.

Individual wells that incurred less drawdown and increased productivity during this study, compared to earlier testing periods, include USGS 17, USGS 38, and USGS 111, USGS 117, USGS 119, and WS INEL 1 (table 3). Decreased drawdown, between testing periods, could be the direct result of changes in well conditions. Changes in well conditions might include cleaning and (or) clearing of the well screen sections, adding additional perforations to well screen sections, and deepening the well. For example, the 2017 aquifer test for well USGS 17 shows $1.32 \mathrm{ft}$ of drawdown at a sustained discharge rate of $30 \mathrm{gal} / \mathrm{min}$; however, in 1989 the well showed $8.70 \mathrm{ft}$ of drawdown at a sustained pumping rate of $32 \mathrm{gal} / \mathrm{min}$ (table 3, fig. 2). Individual well USGS 17 construction logs and geology suggest slotted perforations from 438 to $445 \mathrm{ft}$ BLS along with abundant sediment above and below the perforated section. Given the short-perforated section ( $7 \mathrm{ft}$ ) and abundant sediment throughout the water column, the larger drawdown observed in 1989 may have been the result of a well that was not developed properly and pumping over time developed and cleared the screen.

Individual wells that incurred more drawdown and decreased productivity during this study, compared to earlier testing periods, include USGS 26, USGS 31, USGS 88, USGS
115, USGS 116, and USGS 125 (table 3). Lost production, for individual wells that indicate more drawdown between testing periods, could result from water-level declines between the testing periods and (or) lost well efficiency resulting from well screen plugging. For example, well USGS 26 showed $18 \mathrm{ft}$ of drawdown at a sustained discharge rate of $6 \mathrm{gal} / \mathrm{min}$ in 2017; however, in 1990 when the water level was about $35 \mathrm{ft}$ higher, well USGS 26 showed $0.01 \mathrm{ft}$ of drawdown at a sustained pumping rate of $43 \mathrm{gal} / \mathrm{min}$ (table 3 , fig. 7). Individual well USGS 26 was constructed with slotted pipe that extends from 232 to $267 \mathrm{ft}$ BLS (appendix 1). Without pulling the pump, examining the condition of the slotted pipe section, and collecting geophysical data, it cannot be determined whether the increased drawdown is the result of the overall decline in water levels and (or) the plugging of the slotted pipe. Geophysical data were not available for this well, but it could be used to suggest the location of fractured areas.

The change in specific capacity between testing periods was presented for individual wells (table 3); however, the change in specific capacity is directly related to the sustained discharge rate and should be used with caution. Discharge rates are affected by the type of submersible pump used and changing the pump out can result in a change in the discharge rate observed during the aquifer test. No attempts were made to use the same discharge rate as previous tests; however, the data were presented to show the variability in specificcapacity data. Specific-capacity data variability, presented in table 3, was most useful for wells that had the same or similar discharge rates, but discharge varied between testing periods at some wells.

Over the last 30-year period of record, measured groundwater levels across the INL have declined; however, the northern end of the INL shows more decline than the southern end (Bartholomay and Twining, 2015). Hydrograph data at four select well locations were presented to show the general trend in water levels from north to south and through the center of the INL (figs. 2 and 7). Hydrograph data suggest that water-level response can vary by almost $25 \mathrm{ft}$ between the northern to southern ends of the INL (fig. 7). For example, in the northern end of the INL, water-level decline in USGS 26 was about $35 \mathrm{ft}$ between 1988 and 2018; however, near the southern end of the INL, water-level decline in USGS 9 was about $9 \mathrm{ft}$ for that same period of record (figs. 2 and 7).

The effect of water-level decline on well production becomes a problem when levels drop below water-producing fractures. For wells that have water columns exceeding $50 \mathrm{ft}$ (table 2), the probability of the borehole intersecting additional water-producing fractures at depth is greatly increased; therefore, the well will continue to produce water even if the submersible pump needs to be lowered. Monitor wells with water columns that are less than $50 \mathrm{ft}$ (table 2, appendix 1) are more directly affected by water-level decline. The lengths of open interval for wells vary significantly; the average length for this study is $118 \mathrm{ft}$. 


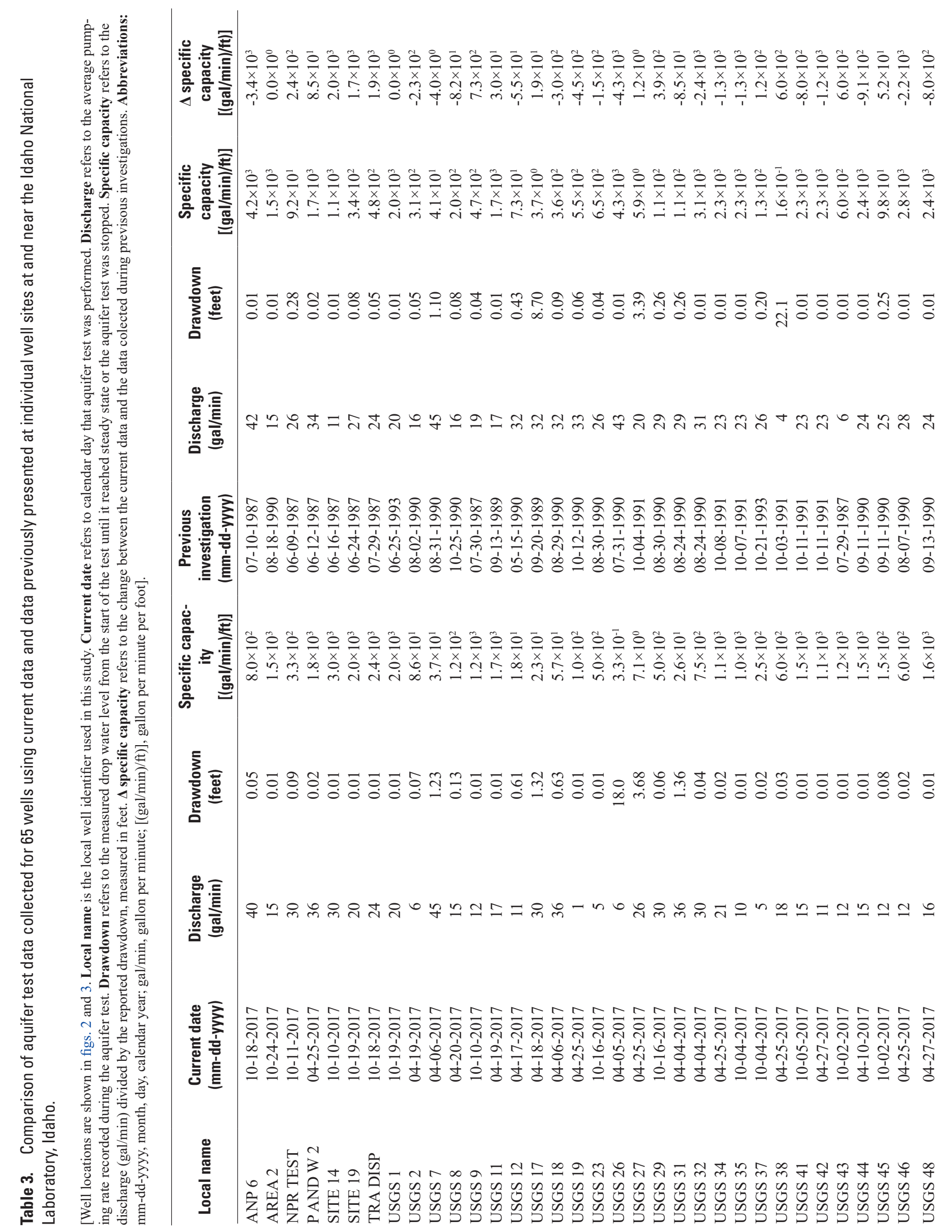




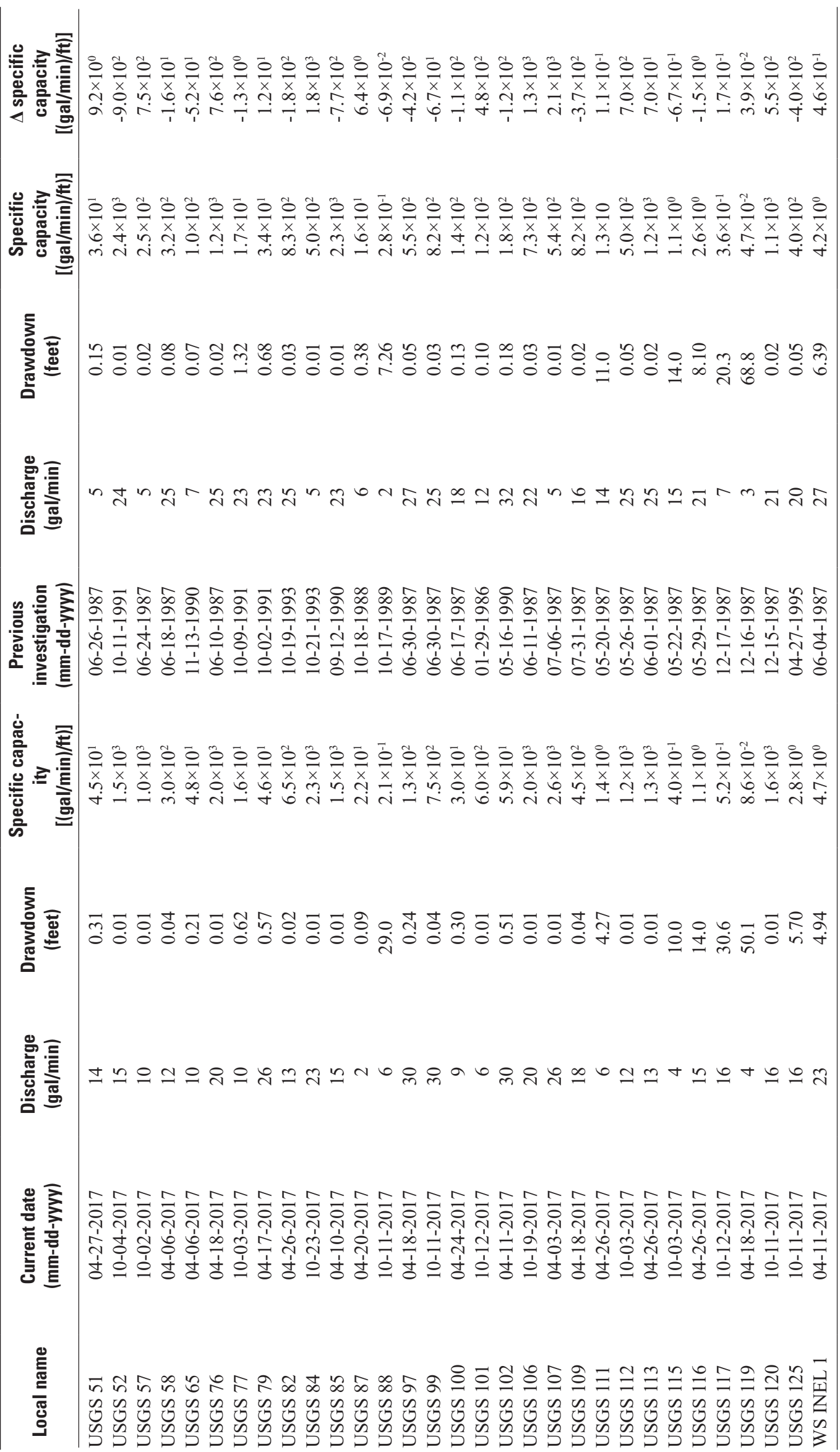


A. Well 435212112394001—USGS 26

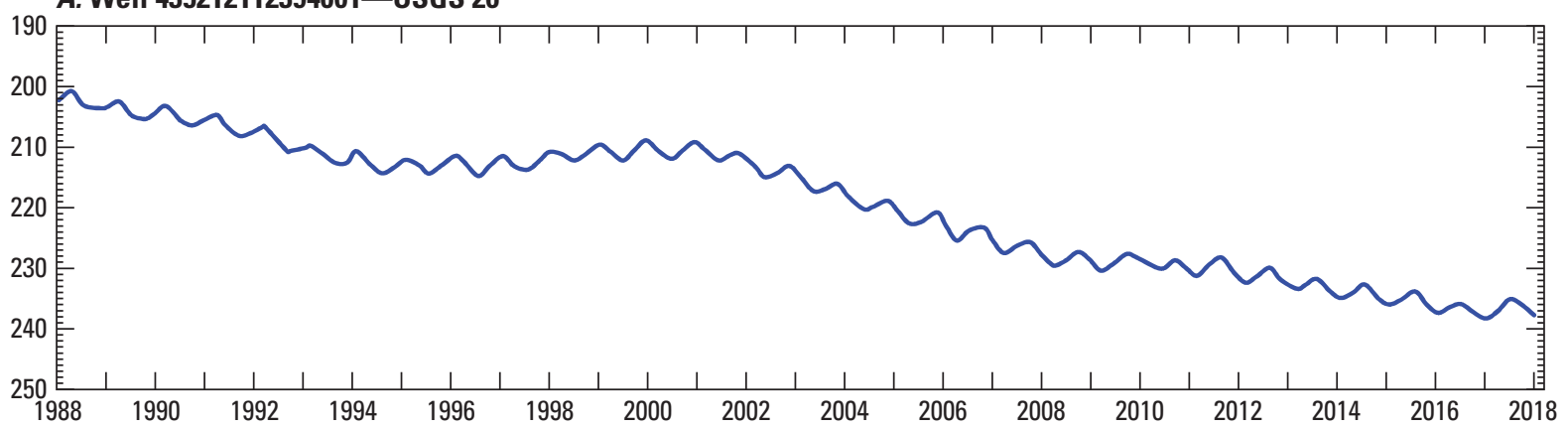

B. Well 434334112463101-SITE 14
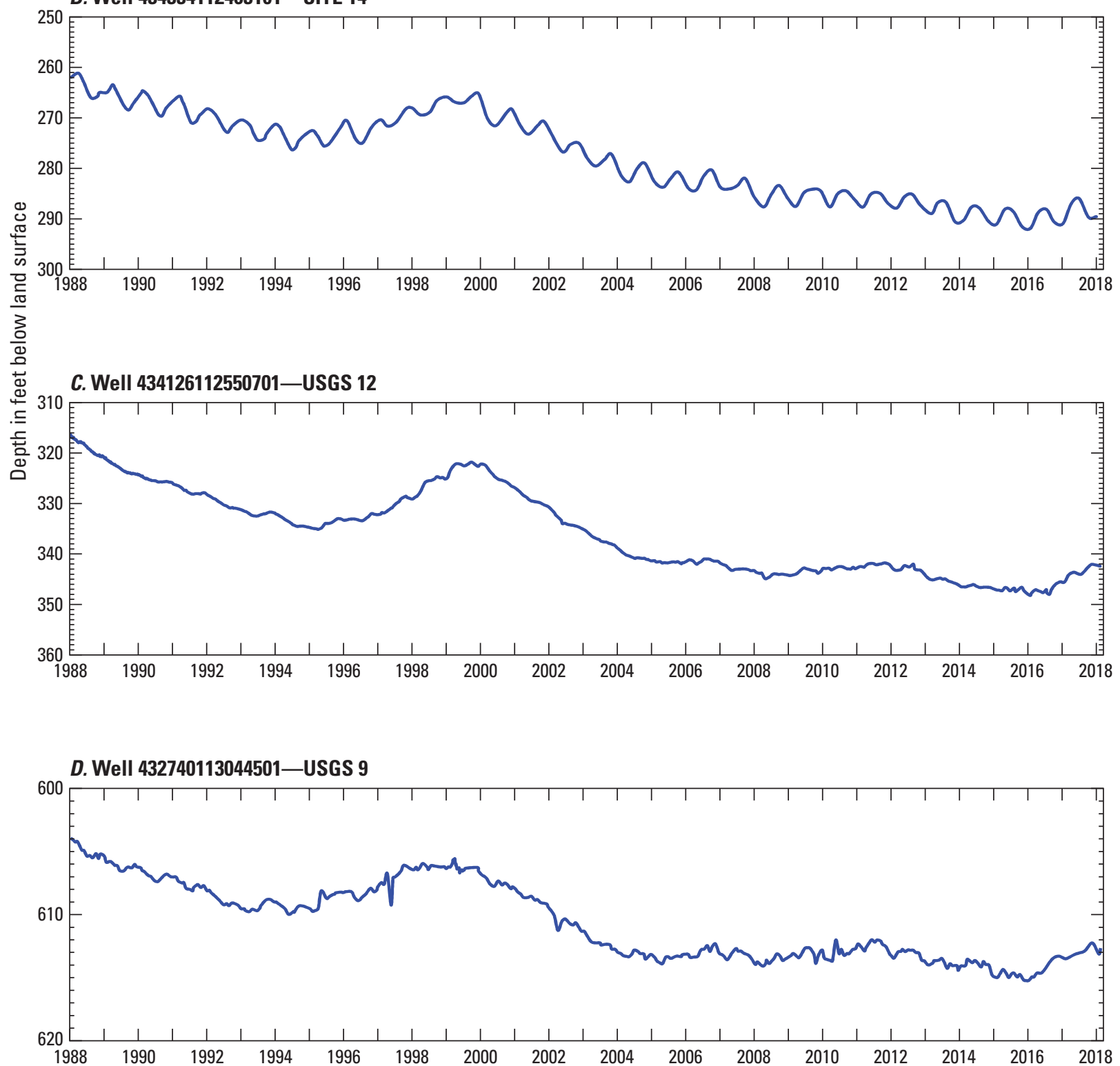

Figure 7. Water levels in wells $(A)$ USGS $26,(B)$ Site $14,(C)$ USGS 12, and $(D)$ USGS 9, indicating water-level change through the center of the Idaho National Laboratory, 1988-2018. 
In some circumstances, wells are deepened to increase the water column height and to improve the production capacity of the well. For example, well USGS 89 was drilled $68 \mathrm{ft}$ deeper in 2018 after it stopped producing water (appendix 1). Aquifer test data, collected after deepening USGS 89, suggest that the well still shows significant drawdown (>38 ft) but the pump is set deep enough to allow the well to still be sampled. The aquifer test data collected at USGS 89 and other neighboring wells were used to support location of subsurface hydrogeologic features likely affecting the ESRP aquifer near this well and others.

\section{Geologic Controls on Estimated Transmissivity}

Transmissivity estimates for individual wells were divided into five categories, ranging from very low to very high transmissivity (table 4). About 53 percent of the wells tested show high or very high transmissivity $\left(>10,000 \mathrm{ft}^{2} / \mathrm{d}\right)$; about 23 percent of the wells tested show low or very low (referred to as "lower") transmissivity $\left(\leq 1,000 \mathrm{ft}^{2} / \mathrm{d}\right)$. About 24 percent of wells tested suggest moderate transmissivity $\left(>1,000\right.$ to $\left.10,000 \mathrm{ft}^{2} / \mathrm{d}\right)$. The data suggest that most wells tested for this study have transmissivity estimates of $>10,000$ $\mathrm{ft}^{2} / \mathrm{d}$.

Geologic features, such as volcanic vent corridors, can affect localized regions of the aquifer when dike swarms and (or) densely ponded basalt restrict the ability of the aquifer to transmit groundwater (Anderson and others, 1999). The location of volcanic vents often is approximated (inferred) because they lie deep within the subsurface at the INL. Basalt flow source vents at and near the INL seem to be concentrated in volcanic rift zones that trend perpendicular to the axis of the ESRP and parallel to the adjacent mountain ranges (Kuntz and others, 1992, 1994). To develop inferred areas of lower transmissivity, the number of vent corridors (Anderson and others, 1999) were compared with well locations that indicate lower transmissivity $\left(\leq 1,000 \mathrm{ft}^{2} / \mathrm{d}\right)$.

Twenty-four wells had lower transmissivity $(\leq 1,000$ $\mathrm{ft}^{2} / \mathrm{d}$ ). These wells overlap multiple vent corridors that extend perpendicular to the axis of the ESRP. Well locations from this study, when mapped against the numbered vent corridors (Anderson and others, 1999), suggest eight inferred areas of lower transmissivity (fig. 8 and table 5).
There are several groups of wells (clusters) relatively near each other that have lower transmissivity $(\leq 1,000$ $\mathrm{ft}^{2} / \mathrm{d}$ ). Using these well clusters, and other wells with lower transmissivity, eight inferred areas were developed that mostly extend out along modified vent corridor boundaries. The inferred areas of lower transmissivity were identified and labeled based on previously described vent corridors (Anderson and others, 1999). For example, a cluster of wells is described south of the INTEC facility (figs. 3 and 8). This region correlates to vent corridor numbers 25 and 27 (fig. 8); therefore, this inferred area was assigned VC-25_27 to suggest wells that overlap two identified vent corridor areas. The inferred area VC-33 is located south of facility RWMC (figs. 3 and 8 ) and extends along a projected vent corridor where seven individual wells (table 5) have lower transmissivity $\left(\leq 1,000 \mathrm{ft}^{2} / \mathrm{d}\right)$, further showing the relationship between vent corridors and transmissivity. Wells constructed within this low transmissivity area, near INTEC and RWMC, fall within a suggested dike swarm and (or) region of tube-fed pahoehoe flows cut by discontinuous dikes (Anderson and others, 1999).

The largest inferred area (VC-23_29_30) of lower transmissivity $\left(\leq 1,000 \mathrm{ft}^{2} / \mathrm{d}\right)$ extends near the Lost River Range through the center of the INL, crossing the southern INL boundary near Atomic City incorporating five wells, and grouping together three volcanic vent corridors (fig. 8). The inferred contact (VC-23_29_30) was extended out to the western border of the INL based on drilling data summarized in Twining and others (2017).

Table 4. Transmissivity categories for monitor well sites at and near the Idaho National Laboratory, Idaho.

[Transmissivity range refers to the calcualted transmissivity presented in table 2 of this report. Number of wells is based on the 101 wells, presented in table 2. Percentage refers to percentage of wells that fall within the transmissivity category. Transmissivity category was based on computed values, but refers to general well productivity ranging from very low to very high. Abbreviations and symbols: $\mathrm{ft}^{2} / \mathrm{day}$, foot squared per day; $\leq$ less than or equal to; $>$, less than]

\begin{tabular}{lccl}
\hline $\begin{array}{c}\text { Transmissivity } \\
\text { range }\left(\mathbf{f t}^{2} \mathbf{d}\right)\end{array}$ & $\begin{array}{c}\text { Number of } \\
\text { wells }\end{array}$ & Percentage & $\begin{array}{c}\text { Transmissivity } \\
\text { category }\end{array}$ \\
\hline$\leq 100$ & 12 & 12 & Very low \\
$>100$ to 1,000 & 11 & 11 & Low \\
$>1,000$ to 10,000 & 24 & 24 & Moderate \\
$>10,000$ to 100,000 & 16 & 16 & High \\
$>100,000$ & 38 & 37 & Very high \\
\hline
\end{tabular}




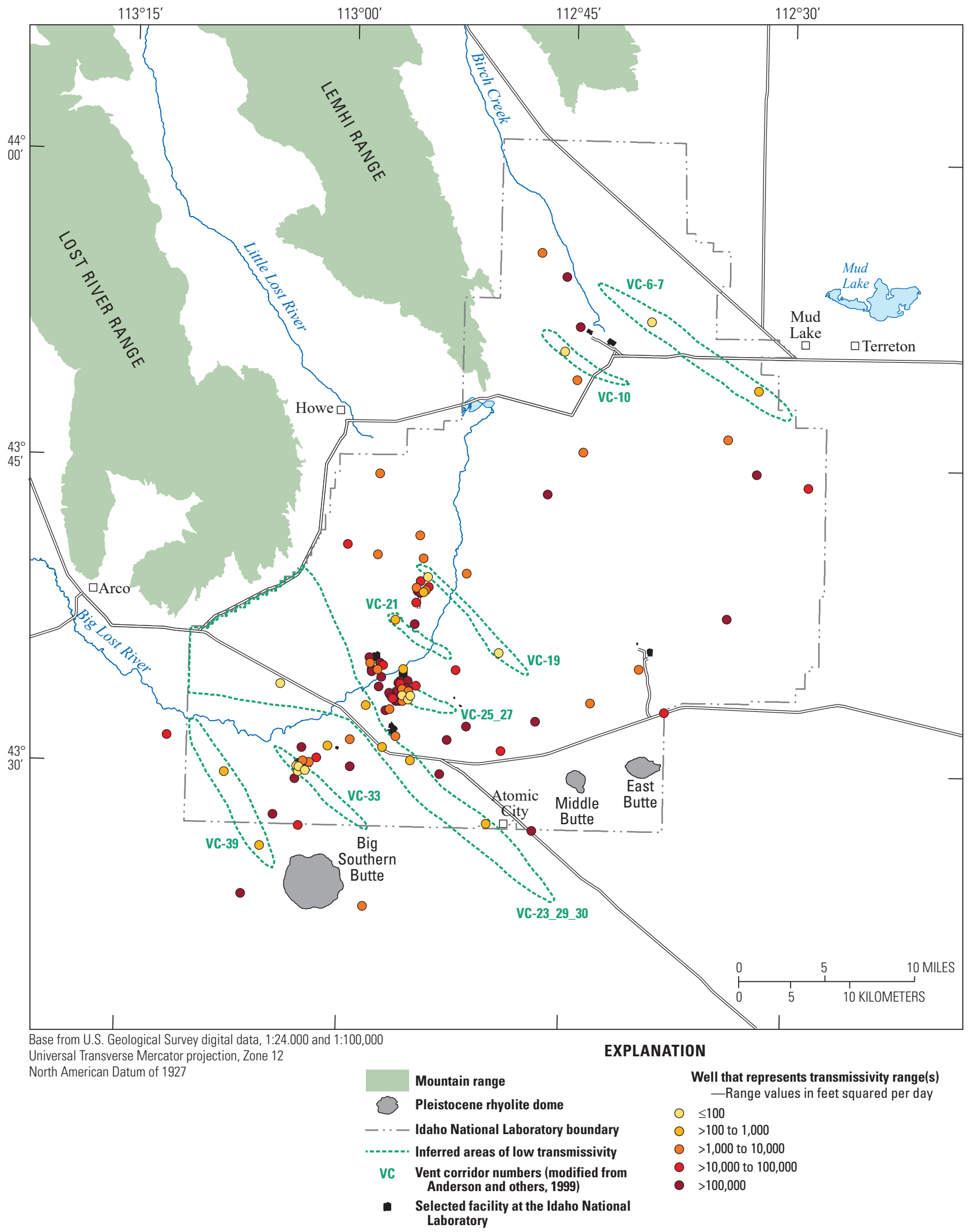

Figure 8. Transmissivity ranges of individual wells and inferred areas of low transmissivity for wells and vent corridors located at and near the Idaho National Laboratory, Idaho. 
Table 5. Relation of individual wells with low and very low transmissivity to vent corridors at and near the Idaho National Laboratory, Idaho.

[Well locations are shown in figs. 2 and 3. Local name is the local well identifier used in this study. Water column height refers to the length of water column measured from the static water surface to the bottom of the well (total well depth). Vent corridor number refers to numbered vent corridors from fig. 7 out of Anderson and others, 1999. Transmissivity category refers to low $\left(100>1,000 \mathrm{ft}^{2} /\right.$ day $)$ and very low ( $\leq 100 \mathrm{ft}^{2} /$ day) transmissivity estimated from aquifer tests and shown in table 4 . Inferred contact labels refer to vent corridor numbers that individual wells intersect that display either a transmissivity category of low or very low (1 or 2). For example well USGS 5 intersect vent corridor 19 so it was labeled VC-19. Some vent corridors were grouped so some labels have multiple vent corridors included. For example USGS 110A shows a larger region of lower transmissivity that crosses 3 vent corridors, it was labeled VC-23_29_30]

\begin{tabular}{lcclc}
\hline Local name & $\begin{array}{c}\text { Water } \\
\text { column } \\
\text { height } \\
\text { (feet) }\end{array}$ & $\begin{array}{c}\text { Vent corridor } \\
\text { number } \\
\mathbf{( 1 ~ t o ~ 4 5 )}\end{array}$ & $\begin{array}{c}\text { Transmissivity } \\
\text { category } \\
\text { (low and very } \\
\text { low) }\end{array}$ & $\begin{array}{c}\text { Inferred contact } \\
\text { labels } \\
\text { (based on vent } \\
\text { corridor numbers) }\end{array}$ \\
\hline ICPP-MON-A-166 & 15 & 27 & Low & VC-25_27 \\
NO NAME 1 & 316 & 10 & Very low & VC-10 \\
NRF 7 & 33 & 19 & Very low & VC-19 \\
NRF 10 & 35 & 19 & Low & VC-19 \\
RWMC M1SA & 48 & 33 & Very low & VC-33 \\
RWMC M11S & 53 & 33 & Low & VC-33 \\
WS INEL 1 & 77 & 21 & Low & VC-21 \\
USGS 5 & 19 & 19 & Very low & VC-19 \\
USGS 26 & 32 & 7 & Very low & VC-6_7 \\
USGS 27 & 69 & 6 & Low & VC-6-7 \\
USGS 86 & 37 & 33 & Low & VC-33 \\
USGS 88 & 63 & 33 & Very low & VC-33 \\
USGS 89 & 107 & 33 & Very low & VC-33 \\
USGS 110A & 73 & 30 & Low & VC-23_29_30 \\
USGS 111 & 84 & 25 & Very low & VC-25_27 \\
USGS 115 & 106 & 25 & Very low & VC-25_27 \\
USGS 116 & 101 & 25 & Very low & VC-25_27 \\
USGS 117 & 64 & 33 & Very low & VC-33 \\
USGS 119 & 34 & 33 & Very low & VC-33 \\
USGS 121 & 34 & 23 & Low & VC-23_29_30 \\
USGS 125 & 16 & 39 & Low & VC-39 \\
USGS 127 & 140 & 29 & Low & VC-23_29_30 \\
USGS 144 & 79 & Low & VC-23_29_30 \\
USGS 146 & 100 & Very low & VC-23_29_30 \\
\hline & & 33 & &
\end{tabular}




\section{Summary}

The U.S. Geological Survey, in cooperation with the U.S. Department of Energy, conducted aquifer tests during 2017-18 on 101 wells at and near the Idaho National Laboratory (INL), Idaho, to define the hydraulic characteristics of wells with pumped intervals (water columns) from 12 to 790 feet (ft) across the eastern Snake River Plain aquifer. Discharge rates during aquifer testing ranged from 1 to 45 gallons per minute (gal/min), water-level change ranged from slight water-level raise(s) (less than $[<] 0.01 \mathrm{ft}$ ) to a drawdown of $52.4 \mathrm{ft}$ (at well USGS 146), and length of aquifer test(s) for individual wells ranged from 10 to 160 minutes. Estimates of specific capacity for individual wells ranged from $<1.0$ to greater than $(>) 3.0 \times 10^{3}$ gallons per minute per foot; estimates of transmissivity for individual wells ranged from 2.0 to $>5.4 \times 10^{5}$ feet squared per day.

Geophysical data, well construction information, and geology for individual wells were presented and used to describe basic hydrogeologic features. Digital geophysical data were presented in figures and used to suggest changes in geologic features and location of fractures and sediment. Well construction information was updated and presented for each of the individual wells. The geology was used to suggest the locations of sediment, sediment thickness, basalt fractures, dense basalt, and rhyolite.

All 101 single-well aquifer tests were analyzed using the specific-capacity method to approximate transmissivity, a simplified approach selected owing to the limited number of aquifer test observations collected. This approach uses a linear regression equation to estimate transmissivity near the well based on drawdown and pumping rate. The data collected are not ideal; furthermore, this method is highly dependent on measured discharge and measured water-level response.

Review of well productivity included examination of aquifer test data for 65 wells collected during this investigation and previous investigations. Furthermore, hydrograph data at four well locations through the center of the INL were reviewed to consider effects of water-level change on well productivity. Eleven of the 65 wells showed a change in well productivity, with six wells having a decrease in well productivity and five wells having an increase in well productivity. Hydrograph data suggest annual fluctuations in water levels, but support declines in water levels over a 30 -year period. Water-level declines can vary by almost $25 \mathrm{ft}$ between the northern and southern end of the INL, with the largest water-level declines at the northern end of the INL at about $35 \mathrm{ft}$ and along the southern end of the INL at about 10 $\mathrm{ft}$. Declines in water levels and changes to well conditions seemed to affect about 17 percent of individual wells; however, 83 percent of wells show minimal impact over the 30 -year period of record between investigation periods.
Estimates of transmissivity were divided into five categories ranging, from very low to very high. About 53 percent of the wells tested suggest high or very high transmissivity, about 23 percent of the wells tested show low or very low transmissivity, and about 24 percent of wells tested suggest moderate transmissivity. This data supports the suggestion that wells constructed in the eastern Snake River Plain aquifer generally are highly productive.

Geologic features, such as volcanic vent corridors, can have a direct effect on hydraulic properties and can affect localized regions of the aquifer. The individual wells in the low and very low transmissivity category seem to correlate to areas also identified as having volcanic vent corridors. There were eight elongated inferred regions that suggest low and very low transmissivity based on aquifer test data from 24 wells. The largest area of low and very low transmissivity seem to extend from the Lost River Range through the center of the INL, crossing the southern INL boundary near Atomic City. There are seven other, less-extensive inferred regions that occur near the southern INL boundary and as far north as Test Area North.

\section{References Cited}

Ackerman, D.J., 1991, Transmissivity of the Snake River Plain aquifer at the Idaho National Engineering Laboratory, Idaho: U.S. Geological Survey Water-Resources Investigations Report 91-4058 (DOE/ID-22097), 35 p. [Also available at http://pubs.er.usgs.gov/publication/ wri914058.]

Ackerman, D.J., Rattray, G.W., Rousseau, J.P., Davis, L.C., and Orr, B.R., 2006, A conceptual model of ground-water flow in the eastern Snake River Plain aquifer at the Idaho National Laboratory and vicinity with implications for contaminant transport: U.S. Geological Survey Scientific Investigations Report 2006-5122, 62 p. [Also available at http://pubs.usgs.gov/sir/2006/5122/.]

Anderson, S.R., Kuntz, M.A., and Davis, L.C., 1999, Geologic controls of hydraulic conductivity in the Snake River Plain aquifer at and near the Idaho National Engineering and Environmental Laboratory, Idaho: U.S. Geological Survey Water-Resources Investigations Report 99-4033 (DOE/ ID-22155), 38 p. [Also available at http://pubs.er.usgs.gov/ publication/wri994033.]

Anderson, S.R., and Liszewski, M.J., 1997, Stratigraphy of the unsaturated zone and the Snake River Plain aquifer at and near the Idaho National Engineering Laboratory, Idaho: U.S. Geological Survey Water-Resources Investigations Report 97-4183 (DOE/ID-22142), 65 p. [Also available at http://pubs.er.usgs.gov/publication/wri974183.] 
Bartholomay, R.C., Maimer, N.V., and Wehnke, A.J., 2014, Field methods and quality-assurance plan for water-quality activities and water-level measurements, U.S. Geological Survey, Idaho National Laboratory, Idaho: U.S. Geological Survey Open-File Report 2014-1146 (DOE/ID-22230), 66 p., http://pubs.usgs.gov/of/2014/1146/.

Bartholomay, R.C., Tucker, B.J., Ackerman, D.J., and Liszewski, M.J., 1997, Hydrologic conditions and distribution of selected radiochemical and chemical constituents in water, Snake River Plain aquifer, Idaho National Engineering Laboratory, Idaho, 1992 through 1995: U.S. Geological Survey Water-Resources Investigations Report 97-4086 (DOE/ID-22137), 57 p. [Also available at http://pubs.er.usgs.gov/publication/ wri974086.]

Bartholomay, R.C., and Twining, B.V., 2015, Hydrologic influences on water-level changes in the eastern Snake River Plain aquifer at and near the Idaho National Laboratory, Idaho, 1949-2014: U.S. Geological Survey Scientific Investigations Report 2015-5085 (DOE/ID 22236), 36 p., https://dx.doi.org/10.3133/sir20155085.

Blackwell, D.D., Kelley, S., and Steele, J.L., 1992, Heat flow modeling of the Snake River Plain, Idaho: Idaho National Engineering Laboratory, U.S. Department of Energy contractor report no. EGG-NPR-10790, 109 p.

Busenberg, E., Plummer, L.N., and Bartholomay, R.C., 2001, Estimated age and source of the young fraction of ground water at the Idaho National Engineering and Environmental Laboratory: U.S. Geological Survey Water-Resources Investigations Report 2001-4265 (DOE/ID-22177), 144 p.

Cecil, L.D., Welhan, J.A., Green, J.R., Frape, S.K., and Sudicky, E.R., 2000, Use of chlorine-36 to determine regional-scale aquifer dispersivity, eastern Snake River Plain aquifer, Idaho/USA, in Nuclear instruments and methods in physics research section B-Beam interactions with materials and atoms: International Conference on Accelerator Mass Spectrometry, 8th, Vienna, Austria, 1999, v. 172 , p. 679-687.

Crain, E.R., 2018, Crain's petrophysical handbook: Shareware web page accessed May 10, 2019, at https://www.spec2000. net/07-neutronlog.htm.

Duke, C.L., Roback, R.C., Reimus, P.W., Bowman, R.S., McLing, T.L., Baker, K.E., and Hull, L.C., 2007, Elucidation of flow and transport processes in a variably saturated system of interlayered sediment and fractured rock using tracer tests: Vadose Zone Journal, v. 6, no. 4, p. 855-867.
Garabedian, S.P., 1986, Application of a parameter-estimation technique to modeling the regional aquifer underlying the eastern Snake River Plain, Idaho: U.S. Geological Survey Water-Supply Paper 2278, 60 p. [Also available at https:// pubs.er.usgs.gov/publication/wsp2278.]

Kuntz, M.A., Covington, H.R., and Schorr, L.J., 1992, An overview of basaltic volcanism of the eastern Snake River Plain, Idaho, in Link, P.K., Kuntz, M.A., and Platt, L.B., eds., Regional geology of eastern Idaho and western Wyoming: Geological Society of America Memoir 179, p. 227-267.

Kuntz, M.A., Skipp, B., Lanphere, M.A., Scott, W.E., Pierce, K.L., Dalrymple, G.B., Champion, D.E., Embree, G.F., Page, W.R., Morgan, L.A., Smith, R.P., Hackett, W.R., and Rodgers, D.W., 1994, Geologic map of the Idaho National Engineering Laboratory and adjourning areas, eastern Idaho: U.S. Geological Survey Miscellaneous Investigations Map I-2330, scale 1:100,000.

Lindholm, G.F., 1996, Summary of the Snake River Plain regional aquifer-System analysis in Idaho and eastern Oregon: U.S. Geological Survey Professional Paper 1408A, $59 \mathrm{p}$.

Lindholm, G.F., Garabedian, S.P., Newton, G.D., and Whitehead, R.L., 1988, Configuration of the water table and depth to water, spring 1980, water-level fluctuations, and water movement in the Snake River Plain regional aquifer system, Idaho and eastern Oregon: U.S. Geological Survey Hydrologic Atlas HA-703, scale 1:500,000.

Lohman, S.W., 1972, Ground water hydraulics: U.S. Geological Survey Professional Paper 708, 70p.

Mann, L.J., 1986, Hydraulic properties of rock units and chemical quality of water for INEL-1-A 10,365-foot deep test hole drilled at the Idaho National Engineering Laboratory, Idaho: U.S. Geological Survey Water-Resources Investigations Report 86-4020 (IDO-22070), 23 p. [Also available at https://pubs.er.usgs.gov/usgspubs/wri/ wri864020.]

Mann, L.J., and Beasley, T.M., 1994, Iodine-129 in the Snake River Plain aquifer at and near the Idaho National Engineering Laboratory, Idaho, 1990-91: U.S. Geological Survey Water- Resources Investigations Report 94-4053 (DOE/ID-22115), 27 p. [Also available at https://pubs. er.usgs.gov/usgspubs/wri/wri944053.]

Nimmo, J.R., Perkins, K.S., Rose, P.E., Rousseau, J.P., Orr, B.R., Twining, B.V., and Anderson, S.R., 2002, Kilometerscale rapid transport of naphthalene sulfonate tracer in the unsaturated zone at the Idaho National Engineering and Environmental Laboratory: Vadose Zone Journal, v. 1, no. 1, p. 89-101. 
Pierce, K.L., and Morgan, L.A., 1992, The track of the Yellowstone hot spot, in Link, P.K., Kuntz, M.A., and Platt, L.B., eds., Regional geology of eastern Idaho and western Wyoming: Geological Society of America Memoir 179, p. $1-53$.

Robertson, J.B., Schoen, R., and Barraclough, J.T., 1974, The influence of liquid waste disposal on the geochemistry of water at the National Reactor Testing Station, Idaho, 1952-1970: U.S. Geological Survey Open-File Report 73-238 (IDO-22053), 231 p.

Schlumberger, 1972, Log interpretation, volume I-Principles: New York, Schlumberger Limited, 113 p.

Shervais, J.W., Vetter, S.K., and Hanan, B.B., 2006, Layered mafic sill complex beneath the eastern Snake River PlainEvidence from cyclic geochemical variations in basalt: Geology, v. 34, no. 5, p. 365-368.

Twining, B.V., Bartholomay, R.C., and Hodges, M.K.V., 2012, Completion summary for borehole USGS 136 near the Advanced Test Reactor Complex, Idaho National Laboratory, Idaho: U.S. Geological Survey Scientific Investigations Report 2012-5230 (DOE/ID-22220), 32 p. plus appendixes, https://pubs.usgs.gov/sir/2012/5230/.

Twining, B.V., Bartholomay, R.C., and Hodges, M.K.V., 2014, Completion summary for boreholes USGS 140 and USGS 141 near the Advanced Test Reactor Complex, Idaho National Laboratory, Idaho: U.S. Geological Survey Scientific Investigations Report 2014-5098 (DOE/ ID-22229), 40 p. plus appendixes, https://pubs.usgs.gov/ sir/2014/5098/.

Twining, B.V., Bartholomay, R.C., and Hodges, M.K.V., 2016, Completion summary for boreholes TAN-2271 and TAN2272 at Test Area North, Idaho National Laboratory, Idaho: U.S. Geological Survey Scientific Investigations Report 2016-5088 (DOE/ID-22239), 37 p. plus appendixes, https:// dx.doi.org/10.3133/sir20165088.
Twining, B.V., Hodges, M.K.V., Schusler, K., and Mudge, C., 2017, Drilling, construction, geophysical log data, and lithologic log for boreholes USGS 142 and USGS 142A, Idaho National Laboratory, Idaho: U.S. Geological Survey Data Series 1058 (DOE/ID-22243), 21 p. plus appendixes, https://doi.org/10.3133/ds1058.

U.S. Environmental Protection Agency, 2014, Protection of environment-National primary drinking water regulations: Code of Federal Regulations, title 40, part 141 [variously paged].

U.S. Geological Survey, 1985, National Water summary 1984-Hydrologic events, selected water-quality trends, and ground-water resources: U.S Geological Survey WaterSupply Paper 2275, 467 p. [Also available at https://pubs. er.usgs.gov/publication/wsp2275.]

U.S. Geological Survey [various dates], National field manual for the collection of water-quality data: U.S. Geological Survey Techniques of Water-Resources Investigations, book 9, chap. A1-A9. [Also available at https://water.usgs.gov/ owq/FieldManual/.]

Whitehead, R.L., 1986, Geohydrologic framework of the Snake River Plain, Idaho and eastern Oregon: U. S. Geological Survey Hydrologic Investigations Atlas HA-681, scale 1:1,000,000, 3 sheets.

Whitehead, R.L., 1992, Geohydrologic framework of the Snake River Plain regional aquifer system, Idaho and eastern Oregon: U. S. Geological Survey Professional Paper 1408-B, 32 p. [Also available at https://pubs.er.usgs.gov/ publication/pp1408B.]

Williams, J.H., and Johnson, C.D., 2004, Acoustic and optical borehole-wall imaging for fractured-rock aquifer studies: Journal of Applied Geophysics, v. 55, nos. 1-2, p. 151-159. 


\section{Appendix 1. Geophysical Logs And Construction Information For Aquifer Test Wells}

Appendix 1 is an Adobe Acrobat ${ }^{\circledR}$.PDF file available for download at https://doi.org/10.3133/sir20195134.

\section{Appendix 2. Aquifer Test Data Collected For Individual Wells}

Appendix 2 is an Adobe Acrobat ${ }^{\circledR}$.PDF file available for download at https://doi.org/10.3133/sir20195134. 
Publishing support provided by the U.S. Geological Survey Science Publishing Network, Tacoma Publishing Service Center

For more information concerning the research in this report, contact the Director, Idaho Water Science Center

U.S. Geological Survey

230 Collins Road

Boise, Idaho 83702-4520

https://www.usgs.gov/centers/id-water 


\section{$\frac{\mathbb{3}}{3}$}

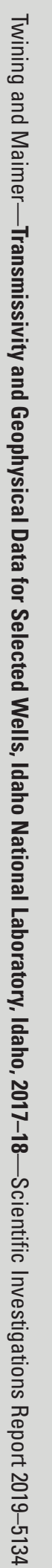

